IFN Working Paper No. 681, 2006

\title{
An Essay on Economic Reforms and Social Change in China
}

\author{
Assar Lindbeck
}


EcRefChina

15/11, 2006

World Bank Policy Research Paper no WPS 4057, Nov. 2006

\title{
An Essay on
}

\section{Economic Reforms and Social Change in China}

\author{
Assar Lindbeck \\ Institute for International Economic Studies \\ Stockholm University \\ and \\ Research Institute for Industrial Economics, Stockholm
}

The author is grateful for useful comments on earlier versions of the paper from Charles Abelmann, Dario Caldara, Gregory Chow, Peter Heller, Bert Hofman, Robert Holzmann, Nick Lardy, Peter Nolan, Martin Ravallion, Zmarak Shalizi, Gordon Tullock, Shuilin Wang, Hans Wijkander, Solveig Wikström, Changgang Xu, Ziaoqing Yu and Ziaobo Zhang. Astrid Wake has helped with literature search and David Zimmerman has checked the references. 


\begin{abstract}
$\underline{\text { Abstract }}$
This paper applies a systems-oriented, "holistic" approach to China's radical economic reforms during the last quarter of a century. It characterizes China's economic reforms in terms of a multidimensional classification of economic systems. When looking at the economic consequences of China's change of economic system, I deal with both the impressive growth performance and its economic costs. I also study the consequences of the economic reforms for the previous social arrangements in the country, which were tied to individual work units: agriculture communes, collective firms and stateowned enterprises. I continue with the social development during the reform period, reflecting a complex mix of social advances, mainly in terms of poverty reduction, and regress for large population groups in terms of income security and human services, such as education and, in particular, health care. Next, I discuss Chinas future policy options in the social field, whereby I draw heavily on relevant experiences in developed countries over the years. The future options are classified into three broad categories: policies influencing the level and distribution of factor income, income transfers including social insurance, and the provision of human services.
\end{abstract}




\section{Contents}

Introduction 4

I. The Nature and Economic Consequences of the Economic Reforms 6

I:1 The Reforms 6

I:2 Economic Consequences 25

II. Social Advance and Regress 35

II:1 Consequences for Previous Social Arrangements 35

II:2 Social Outcomes 38

III. Social Policy Options $\quad 50$

III:1 Policies to Influence Factor Income $\quad 50$

III:2 Income Transfers and Social Insurance $\quad 57$

III:3 Human Services $\quad 67$

A. Education and Training $\quad 68$

B. Health Care $\quad 72$

$\begin{array}{ll}\text { IV. Concluding Remarks } & 78\end{array}$

References $\quad 83$ 


\section{Introduction}

The fascination with the economic development in China during the last quarter of a century (approximately 1978-2006) largely depends on two circumstances. One is the radical shift of economic system in a country encompassing a fifth of the population of the world. The other is the country's successful economic performance in connection with this shift. The most obvious illustrations of the latter are the officially recorded aggregate GDP growth rate of about 10 percent per year, the eightfold increase in per capita household income and the drastic fall in the number of individuals living in "absolute poverty”. However, equally interesting are the social problems that have accompanied this transformation - manifest, for instance, in the fields of income security, the overall distribution of income, and the provision of various types of human services, such as education and health care.

To highlight these issues, this paper applies a systems-oriented, "holistic" approach to China's radical economic reforms. It deals with both the nature of the reforms and their economic and social consequences. More specifically, the paper focuses on the interaction between economic and social forces during the reform period. I also consider China's options for continued economic and social reforms, whereby I draw heavily on relevant experiences over the years in developed countries. Although I concentrate on economic and social developments of the country as a whole, the huge differences across geographical areas within China remain an important aspect of these developments. Since the focus of the paper is on long-term structural issues, the design of short-term macroeconomic stabilization policy will not be discussed, although the importance of such policies for income stability will be stressed.

The paper starts with a characterization of China's economic reforms in terms of a multidimensional classification of economic systems, where today's China is described as a special type of "mixed economy" (Section I:1). When looking at the economic consequences of the reforms, I deal with both the impressive growth performance and various types of economic costs (I:2). The next step is to study the 
consequences of the economic reforms for the previous social arrangements, which were tied to individual work units - agriculture communes, collective firms and state-owned enterprises (Section II:1). I continue with various social developments, which reflect a complex mix of social advances in some respects and regress in others (Section II:2). China’s future policy options in the social field (Section III) are classified into three broad categories: those influencing the level and distribution of factor income (i. e., incomes from labor and capital), income transfers (in particular, social insurance) and the provision of human services. Section IV contains brief concluding remarks about China's achievements and unsolved problems in the economic and social fields. It is unavoidable that the analysis shoots at a moving target - both because the reform process moves on and because of ongoing revisions of the national accounts. ${ }^{1}$

I make no attempt to explain the internal political processes among the Chinese leadership behind the economic reforms. Although Deng Xiaoping stands out as the dominant political leader in the initial stages of the reforms, the views, interest and actions of political leaders at all levels must also have been crucial for the process.

\footnotetext{
${ }^{1}$ When no other sources are mentioned, I rely on official Chinese statistics published by the National Bureau of Statistics of China. I have then taken note of the revisions of the national accounts of China reported in December 2005 (published in Statistical Abstract, 2006). For a short summary of these revisions, see Oxford Analytica, 2005, and People Daily, 2005. For a discussion of the production of statistics in China and the recent revision of the national accounts, see Holz (2005a and 2006).
} 


\section{The Nature and Economic Consequences of the Economic Reforms}

\section{I:1 The Reforms}

The sequence of the economic reforms in China is well known by now. The reforms started with spontaneous, mainly local reorganization in agriculture in the late 1970s, resulting in greater autonomy for individual collective farms, as well as for those working there. These arrangements were codified and further developed in accordance with the so-called Household Responsibility System in 1978/79 and the replacement of collective farms with family farms in the early 1980 s. $^{2}$

In industry, the reforms began in the early 1980s (also rather spontaneously) with an expansion of collective industrial firms in rural areas, so-called Township and Village Enterprises (TVEs), initiated by local political leaders. ${ }^{3}$ Indeed, the TVEs became the most vital part of the manufacture sector in China from the early 1980s to the early 1990s. The economic reform process continued with central policy decisions to increase the autonomy of individual state-owned enterprises, SOEs, in particular as a result of the so-called Contract Responsibility System initiated in the mid-1980s.

These three developments - the shift from agricultural collectives to household farms, the expansion of TVEs, and the reorganization of individual SOEs constitute the starting point for a gradual overhaul of the entire economic system in China. The reform process continued with the privatization of a large number of small and medium-sized SOEs, the entry and expansion of domestic and foreign private firms (the latter, to begin with, in Special Economic Zones, SEZs), a gradually more private character of the originally collective industrial firms ${ }^{4}$ and the

\footnotetext{
${ }^{2}$ See, for instance, Zhou (1996) and Johnson (1996 and 1998).

${ }^{3}$ These firms grew out from so called Commune Brigade Enterprises, formed in the connection with the “Great Leap Forward” and the "Cultural Revolution”. These firms originally took over industrial production from agriculture communes.

${ }^{4}$ In geographical areas with "government-centered" ownership regimes, the TVEs continued to be collectively owned for a prolonged period of time, although increasingly operated by hired managers under various incentive contracts. By contrast, in municipalities with “entrepreneur-centered regimes”, such as in the coastal areas of southeastern China, TVEs were privatized at an early stage of the reform period, and private individuals have dominated the creation of new firms (Oi and Walder, 1999).
} 
liberalization of international trade. While the reforms of the SOEs, in the beginning were limited to reorganizations, from the mid-1990s layoffs of workers and privatization became dominating features of the reform process in this sector. Moreover, today (indeed from the mid-1990s), most TVEs, although still often called “collective”, are basically private firms - partnerships, unincorporated business or producers' cooperatives. (The label "collective” is often presumed to make them ideologically more acceptable and better treated by public authorities and credit institutes; see, for instance, IFC, 2000.)

Since the economic reforms are best characterized as a change of the economic system, it is useful to analyze them in the context of a typology of economic systems. Following a previous paper of mine (Lindbeck, 1975), I will regard an economic system as a multi-dimensional phenomenon, defined here in terms of a nine-dimensional vector; see Figure 1. The first two dimensions concern the ownership of firms and assets, respectively - contrasting public (government) and private ownership. The third dimension deals with the choice between centralized and decentralized economic decision-making, and the fourth with the related choice between administrative processes and market mechanisms for transmitting information, coordinating economic decisions, and distributing goods and services among households. The fifth and sixth dimensions concern the extent to which economic behavior is influenced by non-economic motives and economic incentives, respectively - in the case of individuals as well as firms. The seventh and eighth dimensions refer to one crucial aspect of the relation between the economic agents within the domestic economy: the role of competition. The ninth dimension, finally, concerns the relations between domestic economic agents and the outside world, contrasting autarkic and internationally integrated (“internationalized”) economic systems. 
Figure 1

Dimensions of economic systems

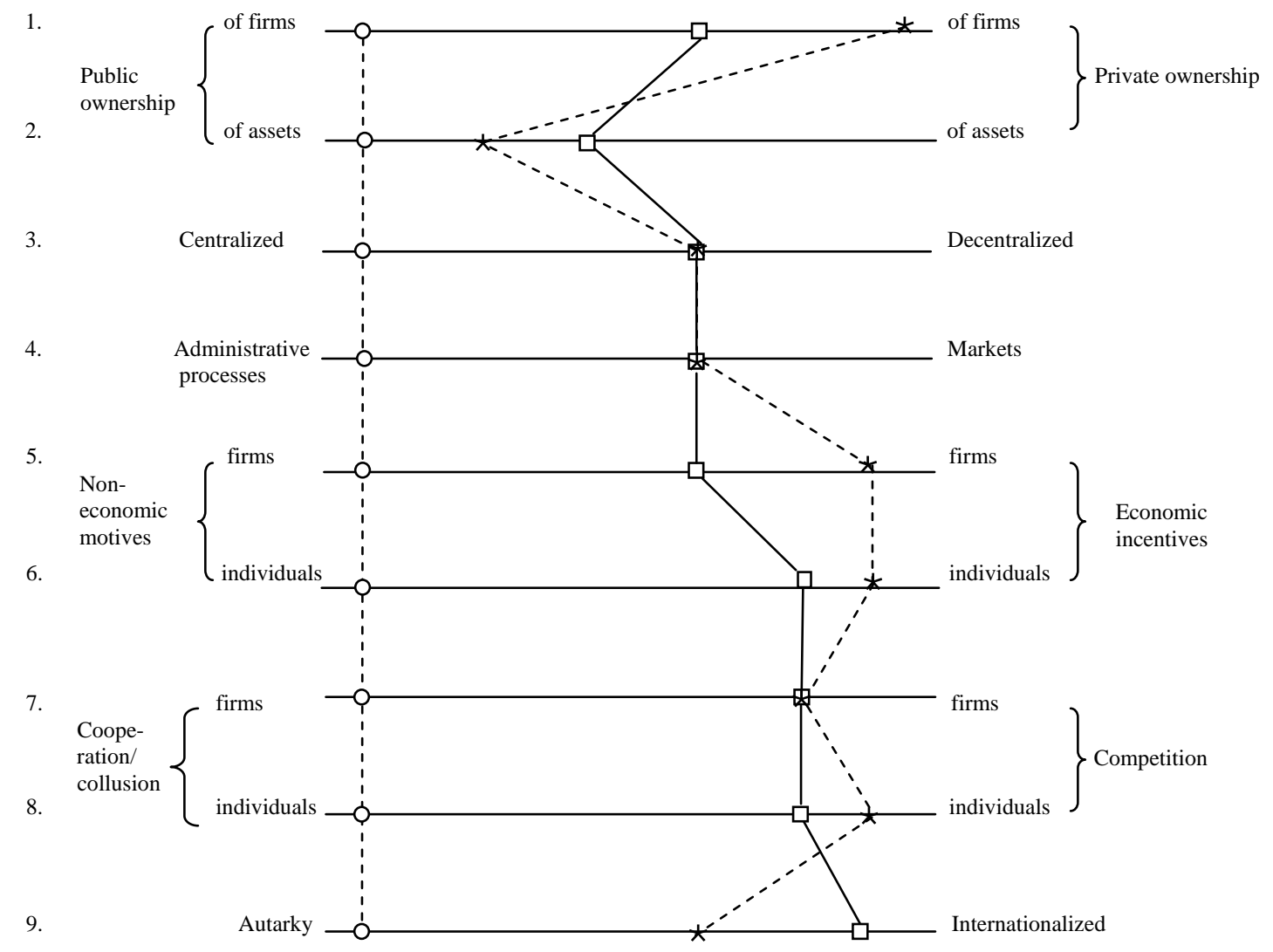

O China before 1978

* Chinese agriculture today

Chinese non-agriculture sectors today 
In terms of Figure 1, I depict the initial (“standardized”) position in the late 1970s by the vertical vector of circles to the far left in the figure. This was clearly a rather consistent system, combining collective ownership with administrative command of production in an economy that was basically disconnected from international markets. Today’s position (2006) is schematically depicted by stars in the case of agriculture, and by squares for the rest of the economy. Thus, the economic reforms may be described as a movement to the right in all nine dimensions. More specifically, there has been a gradual shift towards private ownership of firms and assets and towards more decentralized decision-making and more reliance on markets, economic incentives and competition, as well as a shift from autarky to internationalization. Inconsistencies, or at least tensions, are difficult to avoid when reforming an entire economic system, partly because the reform measures move at different speeds in different dimensions of the economic system. So far, however, China has been able to deal with these inconsistencies rather successfully, although tension between different aspects of the economic system has certainly emerged.

Needless to say, the figure is only illustrative. For instance, there is plenty of room for differing opinions about the relative magnitude of the shifts in different dimensions of the figure. Nevertheless, the typology may serve as a basis for discussions of the nature of the economic reforms. (When I see no specific reason for asserting that a shift is larger in one dimension than in another, the shifts are simply depicted as having the same size in both.)

It is instructive to start with the ownership dimensions (1 and 2). In the case of agriculture, the most characteristic feature of today's ownership structure is a combination of private ownership of firms and public ownership of the most important physical asset in agriculture: the land that is leased by family farms from local authorities. In the figure, this feature of the ownership structure in agriculture is illustrated by a much larger shift to the right in the first dimension than in the second.

In certain limited respects, long-term land-lease contracts give farmers almost the same property rights as ownership. (In rural areas today, the contracts officially last 30 years but are in reality often shorter.) I then refer mainly to the farmers' control of current production and their right to keep the return on additional effort (since the farmer is the residual claimant to value added in both types of contracts). However, in contrast to 
ownership, land-lease contracts do not give farmers the right to enjoy capital gains on land, to borrow with land as collateral, and to transform land into financial assets - for instance, to finance their own retirement or their children's (or grandchildren's) education. ${ }^{5}$ Moreover, as emphasized by Oliver Hart (1995), leasing contracts are, in principle, less “complete” than ownership contracts. For instance, in the case of agricultural land, leasing is associated with higher uncertainty than ownership about the rights and duties of the farmer to invest in the quality of the land.

The land-lease contracts in China have also country-specific limitations, although the situation varies considerably from village to village (Rozelle and Li, 1998). In particular, first-hand contracts are rationed rather than sold on markets. Moreover, in many villages local leaders heavily regulate the second-hand market (Li, Rozelle and Huang, 2000). As a result, the ability of the farmer to consolidate fragmented patches of land is constrained in many villages, as is his ability to change the size of total input of land in the production process. There is also considerable uncertainty concerning property rights of land-lease contracts due to enforced reallocations ("readjustments") of land holds, and the related risk of expropriation, in particular in connection with the re-zoning of land for other purposes; for a discussion of such uncertainties, see, for instance, Wen (2006). We would expect that the uncertainty generated by such reallocations and expropriation risks is an obstacle to investment in agriculture. ${ }^{6}$

The frequent expropriation of land-tenure contracts is also a major source of social misery and discontent in rural areas. For instance, available estimates indicate that about 34 million farmers (partly or completely) lost their land-lease contracts between 1987 and 2001 due to such expropriation (UNDP, 2005, footnote 120). Thus, the combination of private ownership of firms and public ownership of land, with uncertain property rights, is problematic in Chinese agriculture - although this combination has proven to be much more efficient than the old system with collective farms. It remains to be seen to what extent new legislation (from 2003), which regulates local governments' right to re-zone agricultural land, will strengthen the property rights determined by land-lease contracts.

\footnotetext{
${ }^{5}$ There are, however, experiments in rural Suzhouh in Jiangsu Province to let farmers swap land-lease contracts for pensions (Zhu, 2006).

${ }^{6}$ Indeed, several studies find considerable effects on investment of variations across villages in the risk of leader-imposed readjustments of land-tenure contracts, although the consequences for the efficiency of farms are reported not to be large (Li et al., 2000; Jacoby et al., 2002).
} 
Clearly, the move to private ownership of firms has been slower in industry and services than in agriculture, although the process speeded up considerably in the mid-1990s. One important explanation for the delay in privatizing SOEs is the worries among the authorities about increased frictional and structural unemployment, and the related risk of heightened social tension. Lingering socialist ideology has probably also had an important effect: a desire to maintain state control over a number of large production units "strategic firms" or "commanding heights" of the national economy. According to Chow (2006d, p. 268), the implicit party slogan in this field in the late 1990s was: "Retain the control of the large and let loose the small”. A more pragmatic reason for the reluctance to privatize large SOEs could be industrial policy ambitions: to create a number of large oligopolistic players on world markets in the future - along the lines, for instance, of French industrial policy (a point made by Nolan, 2004). Moreover, private agents may have been reluctant to buy SOEs with large overstaffing or weak financial position. Some state banks may also have resisted the privatization of firms to avoid realizing losses on their loan stock. ${ }^{7}$ However, in spite of various obstacles to the privatization of SOEs, it seems that the bulk of aggregate production (GDP) in China today takes place in privately controlled firms. ${ }^{8}$

While the shift to private ownership of firms has been smaller (and slower) in industry and services than in agriculture, the shift to private ownership of assets has been larger. In particular, while the dominant physical asset in agriculture - land - is publicly owned, the physical assets used by private firms outside agriculture are often privately owned, although rental arrangements exist here as well. (A reason why the shift is larger in the ownership of firms than of assets in the non-agriculture sector is just that some real assets are rented.) Private accumulation of assets has taken place not only via high private saving but also as a result of "asset stripping”, when public wealth has been turned over to

\footnotetext{
${ }^{7}$ A cross-regional regression study by Guo and Yao (2005) finds that not only large overstaffing but also huge debt to banks, in fact, have reduced the probability that a firm will be privatized.

${ }^{8}$ By privately controlled firms I mean all production units in China except wholly or majority-owned SEOs and those "collective firms" that are still owned mainly by local governments. OECD (2005a, Table 2.1) estimates that about 60 percent of aggregate production in China in 2004 was accounted for by the private sector; Tseng and Zebregs (2002) have presented similar figures. We would expect that the recent revision of the national accounts (presented in late 2005) has increased the statistically recorded private share, since the revision has raised the recorded size of the tertiary sector by about 9 percent of GDP. Indeed, in a speech to the yearly congress of Chinese Economists Association on July 3, 2006, the Deputy Finance Minister of China, Jiwei Lou, stated that private firms today account for 70 percent of aggregate output.

Since about half the population still works in agriculture, the private share of the Chinese economy is even larger in terms of employment.
} 
private individuals, for instance, in connection with management buy-outs. It is likely that the private share of (physical and financial) assets will continue to rise further in the future, due mainly to the large volume of plowed-back profits in private firms and the high household saving rate (20-25 percent of households' disposable income). Of course, this prediction is based on the assumption that neither capital formation in state firms nor government holdings of financial assets will increase even more dramatically.

The delay of the privatization of firms and assets has not prevented fairly speedy reforms in other dimensions of the economic system. In particular, economic decision-making has largely been decentralized to households (in the case of consumption) and to firms (in the case of production) - schematically depicted in dimension 3 in Figure 1. For the time being, however, it is difficult to say whether the degree of decentralized decision-making is greater in agriculture or in industry. While individual household farms today have basically full authority to make production decisions themselves, government authorities continue to intervene frequently in individual SOEs, in particular in large ones, as well as in remaining truly collective firms (basically TVEs still owned by towns and villages); see, for instance, Chow (1997, 2002). The autonomy of publicly owned firms is also (indirectly) constrained by the fact that political authorities often appoint the managers of such firms, in particular of large firms. From these specific points of view, decentralization of decision-making has not progressed as far in industry as in agriculture. On the other hand, the absence of private ownership of land is a more severe constraint on the autonomy of investment decisions in farming than in other sectors. In Figure 1, I have therefore simply assumed that it is impossible to say in which sector the decentralization of decision-making has advanced the most.

It should be observed that the characterization of the economic system in China today as rather decentralized refers to the relation between government authorities, on one hand, and firms and households, on the other hand - regardless of whether the relevant government agencies represent the national government, provinces or local authorities. By contrast, the government administration itself is highly (regionally) decentralized, in spite of the centralization of broad political powers to Beijing. Indeed, such (regional) administrative decentralization within the public sector existed already before the initiation of the economic reforms; see, for instance, Wong (1985). In this sense, the 
administrative decentralization may be regarded as an inheritance from the pre-reform period.

Concretely the decentralization of public-sector administration in China shows up, for instance, in great provincial and local government powers in the fields of infrastructure investment, government regulations of trade, and various social arrangements (social insurance as well as human services). The regional decentralization of public-sector administration is therefore an important factor behind the economic and social heterogeneity in China. It is also reflected in the small share of public-sector employees that work for the central government. ${ }^{9}$ An obvious advantage of the administrative decentralization is that local initiatives, and local preferences, can play an important part. It is, however, often difficult to clarify who is responsible for what in cases when central political ambitions are not followed up at local levels.

An important prerequisite for the shift to decentralized economic decision-making to households and firms in China is, of course, that markets and hence price formation have largely replaced administrative processes as the basic mechanism for allocating resources and coordinating decentralized decision-making (dimension 4 in Figure 1). Indeed, markets are the only realistic method for coordinating decentralized decision-making and hence exploit decentralized and fragmented knowledge in society (a point emphasized, in particular, by Hayek, 1945). In fact, since the mid-1990s, market forces in China determine the prices of the vast majority of products. ${ }^{10}$ There are, however, important exceptions. One is the market for natural resources. Moreover, while in the case of industry market forces are constrained by government interventions to mitigate unemployment, in agriculture they are constrained both by the absence of a market for land ownership and by government interventions in the marketing of grain. Therefore, it is an open question in which sector the shift to market prices has been most pronounced.

It is also difficult to generalize about the relative importance of economic incentives in agriculture and industry (dimensions 5 and 6 in Figure 1). I would, however, argue that incentives play a greater role for firms in agriculture than in industry. While farmers make

\footnotetext{
${ }^{9}$ According to the Deputy Finance Minister of China, Jiwei Lou, only about six percent of the employees in public-sector administration work in the central administration (address to conference of China's Economists Society, Shanghai, July 1, 2006).

${ }^{10}$ See, for instance, Iskander (1996) and Beijing Normal University (2003).
} 
production and investment decisions based on the expected economic rewards to their family members, provincial and local political interventions limit the role of economic incentives for many firms. Indeed, these interventions by government officials and politicians in individual SOEs - in particular in the case of investment, export and employment - is the background for Gregory Chow's characterization of China as "a bureaucratic market economy” (1997, 2002, Chapt. 19). As a result, there are tensions between market signals and political signals for the management of SOEs, with unclear responsibilities and principal agent problems as a consequence.

The important role of economic incentives for agriculture farms directly translates into strong economic incentives (economic rewards and punishment) for individuals working on the farms. By contrast, the role of economic incentives for individual employees in industry and services depends on the system of wage formation. Indeed, while state firms today are quite free to set wages for their employees, the latter still often enjoy higher wages than employees in other firms. This is the case, in particular, when state firms have monopoly positions in product markets (such as in the case of public utilities).

It should be noted, however, that low marginal tax rates on work and saving contribute to maintaining economic incentives in all sectors, as compared to the situation in a number of high-tax developed countries today. Very few individuals are subject to marginal income tax rates above 20 percent, although a small group of high-income earners pay 45 percent. An important explanation is, of course, that total government spending is less than 20 percent of GDP (18 percent in 2004 according to the 2005 revision of the national accounts). Another explanation might be that the authorities have been careful not to diminish economic incentives for entrepreneurship and investment in human and physical assets.

Competition has certainly also increased dramatically during the reform period - for firms as well as for individuals. But it is difficult to determine whether the degree of competition among firms (dimension 7 in Figure 1) is stronger in agriculture than in industry and services. The character of this competition obviously differs: atomistic in agriculture but strategic - reflecting "rivalry" - in most other sectors. It seems, however, reasonable to argue that individuals are less protected against competitive forces in agriculture than in industry. While market forces automatically expose individual 
members of farm households to competitive pressure (which may take the form of declining income), employees in SOEs are still relatively protected through incomeinsurance arrangements and in some cases (although much less than earlier) also by direct job protection.

Turning to the last dimension in Figure 1, the pronounced openness of the Chinese economy is one of the most remarkable features of the reforms. Naturally, the large export share - about 30 percent of GDP in 2005 as measured by the official exchange rate - is only one among several measures of the high degree of internationalization of the Chinese economy. Another is that fixed investment by firms registered outside mainland China has amounted to 4-5 percent of GDP during the last decade, or about 10 percent of investment in real capital assets. ${ }^{11}$ While these investments, to begin with, mainly took the form of joint ventures, they have recently occurred more often in non-mainland owned firms. Indeed there is a close relation between investment by firms owned by agents outside mainland China and the export performance of the country, since about half of China's export emanates from such firms. ${ }^{12}$ This development has been facilitated by the important role of entrepreneurs of Chinese origin living outside mainland China, mainly in Hong Kong, Macau, Taiwan/China and Singapore. However, some of the financing of these investments, in fact, originates in mainland China. Agents in other areas have then simply functioned as financial intermediaries for "roundtrips” of capital flows (Garnaut and Song, 1999), perhaps because of tax considerations or ambitions to balance political risks.

Most likely, the internationalization of the Chinese economy, which has been more important in industry than in agriculture, results not only in traditional static (text-book type) gains from trade and international capital mobility, but also in efficiency-enhancing international competition and greater opportunities to learn from foreign firms. ${ }^{13}$ It is also likely that China's interaction with the rest of the world influences the values and life styles of the domestic population. We may expect the emergence of more individualistic

\footnotetext{
${ }^{11}$ These figures can be derived from official statistics on investment by non-mainland firms, assuming an aggregate investment ratio of 43 percent of GDP. (Statistical Yearbook of China, 2005, Table 6.1). ${ }^{12}$ Chow's (2006c) estimate is 60 percent. Moreover, in 2003 about 27 percent of value-added in industrial enterprises with annual sales revenues in excess of $5 \mathrm{~m}$ yuan (USD 0.6m) within China was produced by firms funded outside mainland China (Holz, 2005b).

${ }^{13}$ Indeed, there is empirical evidence of such learning among Chinese firms (Li et al., 2006).
} 
(and perhaps also hedonistic) values, in particular among the urban young - a process that already seems to be underway.

China's choice of a strongly outward-oriented development strategy, subsequently codified by its entry into the WTO as of 2001, must have come as a surprise to observers who, a few decades ago, asserted that such a strategy is mainly suitable for modest-sized countries. These observers were clearly wrong. ${ }^{14}$ It is unlikely, however, that such a huge country as China will continue to have a similarly high export share in a long-term perspective. In particular, the statistically recorded export share of GDP in current prices is bound to fall when real wages, and hence the relative prices of non-tradables, rise in the future. ${ }^{15}$ Moreover, with higher skills and better technology, China is likely to expand its domestic production of components of manufactured goods. We may speculate that this will reduce the country's dependence on international trade.

In principle, China's increased presence on world markets would be expected to boost the potential gains from trade also for developed countries, since such gains tend to increase by the difference in factor proportions among trading partners. In other words, HeckscherOhlin type of trade, based on different factor proportions, would be expected to increase. Nevertheless, it is an open question to what extent the outside world will allow China to continue its distinctly outward-oriented growth strategy. ${ }^{16}$ To a considerable extent, this probably depends on the ability of today's developed countries to adjust to the new global competitive situation, with an increased presence on the world market of not only a number of large developing countries, including India and Brazil, but also former Soviet republics and previous socialist countries in Eastern Europe - all with abundant labor and low real wages as compared to developed countries.

China has, of course, already exerted considerable influence on the market for laborintensive products in developed countries. However, worries are often also expressed in these countries to the effect that China is already becoming an important exporter of high-

\footnotetext{
${ }^{14}$ During about two decades of exceptionally fast GDP growth, Japan - and not just the four small

“Asian Tigers” (Hong Kong, Taiwan/China, Singapore and South Korea) - recorded export-growth rates similar to recent rates in China (Siebert, 2006).

${ }^{15}$ For low-wage countries, such as China, the export share is much lower when measured in terms of PPP than in terms of the official exchanges rate. Such calculations are, however, quite hazardous.

${ }^{16}$ According to the WTO (2006), China's share of world exports (total merchandise trade in current USD) has increased from 0.9 percent in 1980 to 6.5 percent in 2004.
} 
tech and high-skill products. For instance, many observers point to the fact that China's export-product mix is more similar to that of the OECD countries than we would expect on the basis of China's modest per capita GDP. ${ }^{17}$ In a short- and medium term perspective, these worries are, however, exaggerated. China is a large importer of hightech components, which are assembled to finished products with the help of low-skilled labor, for sales both in domestic and foreign markets. Thus, the value added of Chinese export of such products is still mainly low-tech and low-skill. ${ }^{18}$ Developed countries will have an overwhelming comparative advantage, and a trade surplus, in high-tech and highskill products as long as China continues its large import of high-tech and high-skill components in domestically produced final products. Over time, the situation is, of course, bound to change. The value added share of Chinese export would be expected to continue to rise as a result of the gradual upgrading of the high-tech and high skill components of China's export production. Trade between China and today's developed countries will then increasingly consist of intra-sector trade based on specialization within different kinds of high-tech and high-skill product areas.

Two other characteristics of China's economic system - not explicitly highlighted in Figure 1 - should also be mentioned. One is that factor markets, in particular the market for capital and credit, have been reformed less than product markets. There is, however, an emerging labor market, with gradually more flexible relative wages and an increased return on investment in human capital; see, for instance, the discussion in Zhang et al. (2005) and Meng (2005). One background factor is that state firms, which used to shoulder the main responsibility for providing and securing jobs, increasingly adjust their workforce to what is needed for actual production, and this has resulted in large shedding of workers since the second half of the 1990 s (Dong and $\mathrm{Zu}, 2006) .{ }^{19}$ As a result, "lifetime employment” in state firms and truly collective firms is gradually becoming replaced by less permanent and more market-oriented labor contracts. ${ }^{20}$ But the flexibility

\footnotetext{
${ }^{17}$ For an attempt to measure this similarity and its development over time, see, for instance Schott (2005).

${ }^{18}$ The research on this issue is still rather thin. See, however, Cao (2004); Hsiung (2002); Leydesdorff and Ping (2005); and Schwaag Serger and Widman (2005).

${ }^{19}$ The number of workers in the SOEs fell from 110 to 66 million between 1995 and 2003, and the number of workers in collective enterprises from 31 to 10 million (Ministry of Labor and Social Security, 2005). 10-20 percent of those previously employed by state firms were still counted as "laidoff workers” (xiagang gong) several years afterwards; see, for instance, Cook (2000).

${ }^{20}$ About half the workforce of SOEs seems to have been on terminable labor contracts in the late 1990s (State Bureau of Statistics of China, 1998; Hussain, 2000a).
} 
of the labor market is still constrained by the lingering overstaffing in many state firms. Workers usually do not voluntarily leave such firms because important social benefits are still tied to the individual's employment contract. Since these arrangements imply that employees in SOEs are privileged relative to other employees, the urban labor market has a pronounced insider-outsider character. The difference between the situation for state firms and private firms is, however, likely to continue receding over time.

As a result of these features of today's labor market, labor mobility in China is to a considerable extent provided by rural-urban migration rather than by labor mobility within the group of favored urban residents (Knight and Yueh, 2004). One explanation is that the residence registration system in urban areas, hukou, has recently become more lenient, so that it does not prevent migration to cities to the same extent as earlier. Indeed, the urban share of the total population has increased from about 18 percent in 1978 to about 42 percent in 2004 (based on addresses rather than registration). A large number of the migrants to cities constitute, however, the so-called "floating" population, without residence permits or only with temporary permits to live in the city - a group often estimated at about 140 million. Many of these migrants not only perform particularly hard and dangerous jobs. They also have much less social protection (if any), and they have to pay much more than others in urban areas for human services, such as education and health care. Moreover, they are reported to be less rewarded for their effort and for their investment in human capital (Maurer-Fazio and Dinh, 2002); however, studies of this issue are complicated by the difficulties of identifying migrants with similar characteristics as permanent urban residents. This means that the hukou system accentuates the insider-outsider nature of the urban labor market, where immigrants without even temporary residence permit are the most pronounced outsiders.

During a comparable phase of industrialization, today's developed countries in Europe also experienced a huge outflow of labor from agriculture. A considerable share of the rural population could, however, emigrate to other continents with ample availability of agricultural land and expanding urban labor markets. China’s current agricultural population does not have the same opportunities. We would expect this fact, in combination with gradually increasing leniency of the hukou system, to retard the rise in real wages for low-skilled workers in urban areas, and hence keep China highly competitive in labor-intensive products for a long time to come. Another likely result is 
an accentuation of unemployment problems in the future, although high flexibility of relative wages could, in principle, mitigate this problem. ${ }^{21}$ For some time to come, urban labor markets may therefore continue to exhibit characteristics similar to Arthur Lewis's (1954) model of “unlimited supply of labor” in urban areas, although at gradually rising, rather than constant, real wages for low-skilled workers (in the connection with higher labor productivity). ${ }^{22}$

Largely as a result of the huge public ownership of financial assets, it is reasonable to say that financial markets in China are less developed than labor markets. In particular, this holds for securities' markets. For instance, only very few non-state firms are listed on the Shanghai and Shenzhen stock exchanges, and the bulk of the shares of incorporated state firms are not available for purchase. ${ }^{23}$ The efficiency and flexibility of the stock market are also constrained by the poor financial transparency of listed companies, although the transparency is higher for SOEs that have recently issued shares (often in the form of Initial Public Offerings, IPOs) in Hong Kong and on foreign stock markets (mainly New York). Moreover, the bond market is very thin, only constituting about 20 percent of GDP, and bond issues by the government and SOEs dominate the market. Indeed, the bulk of the stock of bonds is also held by government agencies, partly because of the near absence of insurance companies and private pension funds. Moreover, for bonds to play an important part in Chinese financial markets, deregulations of the bond market would be necessary, including a lifting of interest ceilings and a removal of de facto bond issue controls.

In contrast to the thin securities market, the volume of bank assets is quite large in China, mainly because of the huge household saving in the form of bank deposits. While in other East-Asian countries banks tend to intermediate 30-40 percent of the total financial capital in the national economy, the corresponding figure in China seems to be above 70 percent (McKinsey Global Institute, 2006). Since large firms in China, in fact, get their main financing from banks rather than from the poorly developed securities markets, small and

\footnotetext{
${ }^{21}$ Indeed, the UNDP (2000, p. 58) makes already now the judgment that the "explosive increase in unemployment has become the most challenging issue in China's economic and social development". ${ }^{22}$ The Harris and Todaro (1970) model of urban unemployment seems less relevant for China since the unemployment rate for migrants to cities is lower than the unemployment rate for permanent residents; see Giles et. al.(2005)

${ }^{23}$ The International Finance Corporation (IFC, 2000) reports that among 976 listed companies only 11 were non-state firms in 2000.
} 
medium sized firms (SMEs) have been squeezed out from the formal loan market, and they have been forced to turn to the informal financial markets with much higher interest rates. $^{24}$ The efficiency and flexibility of the market for bank loans are also limited by the domination of public-sector banks, which have systematically favored state enterprises at the expense of private firms. ${ }^{25}$ In the late 1990s and early 2000s, two-thirds of all bank credit seems to have been granted to the state sector. Thus, even though private firms produce most of GDP today, China's character as a market economy is still constrained by the domination of government institutions in financial markets.

Another well known weakness of financial markets in China is that bank lending often has been "soft" in the sense that a large fraction of the loans have turned out to be nonperforming (paying neither interest rates nor amortization). Indeed, according to many observers, 30-40 percent of the stock of loans by public-sector banks was non-performing around year $2000 .^{26}$ It is often also asserted that many bank managers expected government authorities to bail them out in the event of severe financial difficulties in the future - if so, a pronounced example of moral hazard in the financial system.

The share of non-performing loans is believed to subsequently have fallen to less than 10 percent due to the transfer of a large volume of such loans to special asset management companies, as well as due to the recapitalization of some of the banks by government funds. ${ }^{27}$ The large flow of deposits of household saving into state banks at low (occasionally negative) real interest rates has also helped avoid an acute financial crisis in the bank system.

For these reasons, the risk of an immanent financial crisis in China is remote. Indeed, the Chinese government has sufficient financial resources to avoid financial instability in the near future, even with a "new round” of non-performing loans, and only modest recovery

\footnotetext{
${ }^{24}$ McKinsey Global Institute (2006, pp. 65-66) estimates the informal loan market at US \$ 100 billion (about 5 percent of GDP), with interests often in the interval 15-20 percent.

${ }^{25}$ According to the OECD (2005a, Figure 3.2), more than 90 percent of total bank assets are owned by the public-sector banks.

${ }^{26}$ See, for instance, Lardy (2000); Chow (2002, pp. 229-30); Aziz and Duenwald (2002); Asian Development Bank (2004); and OECD (2005a, Table 3.4).

${ }^{27}$ See, for instance, (2006, March 25) and Dobson (2006). The latter study calculates that the Chinese taxpayers have injected US \$ 231 billion since 1999 to fix up the balance sheets of three of China’s Big Four Banks. McKinsey Global Institute (2006, p. 32) estimates that more than US \$ 300 billion worth of nonperforming loans has been transferred from the large state commercial banks to asset-management companies since their creation in 1998.
} 
of the loans that have been shifted over to the asset management corporations. ${ }^{28}$ However, in a long-term perspective, financial stability, and indeed macroeconomic stability, clearly requires that the quality of lending by financial institutions in China improves considerably. It is therefore disturbing that the large expansion of bank loans in China in recent years (a rate of expansion of about 20 percent per year) has continued to favor state firms; according to McKinsey Global Institute (2006, Exhibit 2) they have received about two thirds of the loans. Indeed, several observers have expressed concern about the quality of this lending; see, for instance, Goldstein and Lardy (2004).

Moreover, while future deregulation and increased competition in financial markets are important for improving the efficiency of these markets, such policies could during a transition period also contribute to financial instability through reduced profit margins. These observations underline the importance of improving the quality of lending in China sooner rather than later. (I will return to the consequences of deficiencies in Chinese financial markets for the efficiency of the allocation of resources in the country $-\mathrm{a}$ serious problem even if it turns out to be possible to avoid financial crises in the future.)

Another characteristic feature of the economic system in China is the heavy reliance on informal networks, partly as substitutes for "the rule of law" (i.e. the enforcement of contracts through the legal system). Observers of the Chinese business culture often refer to the so-called guanxi - the Chinese variety of "social capital”. ${ }^{29}$ More specifically, economic relationships among economic agents are largely founded on social norms of cooperation, with roots in traditional kinship and community institutions. Indeed, such norms may function as de facto property rights, thereby stabilizing expectations regarding the behavior of other economic agents (Wank, 1999). These norms are then based on a distinction between business insiders (neiren) and business outsiders (wairen). The former are identified in terms of family relations or "sameness", for instance, among schoolmates, colleagues and neighbors. Such networks also involve informal financial markets (Allen, Qian and Qian, 2006). The networks of individuals sharing the same social norms are often extended by close ties to local officials - ties that are crucial in a society where legal rights are often enforced in a haphazard manner.

\footnotetext{
${ }^{28}$ According to McKinsey Global Institute (2006, p. 32), the recovery rate of these assets has only been about 20 percent so far.

${ }^{29}$ See, for instance, Walder (1996); Chow (1997, 2002); and Peerenboom (2003).
} 
Although the networks often facilitate economic transactions, they are not unproblematic. In particular, "kickbacks" and other types of corruption are difficult to avoid with close "clientele-like” relations among representatives of the public-sector, managers of state firms and private entrepreneurs. The two most obvious examples of corruption are perhaps (i) that politicians and public-sector administrators take bribes from firms that need various types of permits; and (ii) that public-sector representatives or managers of state firms transfer public-sector resources to themselves, so-called "asset stripping”. Indeed, during the reform period. China has been wide open for both types of corruption because of lingering regulations, permit requirements, large public-sector ownership of firms and assets, and a privatization process in the context of a weak legal system.

As would be expected, international studies suggest that corruption often distorts the allocation of resources, as compared to a hypothetical situation with a market economy based on the "rule of law"; see, for instance, Svensson (2005). However, if we look at the situation in specific countries, the overall consequences for economic efficiency and economic growth are often quite complex. In particular, the consequences seem to depend on a number of country-specific circumstances, such as the industrial structure and the political system, including the time horizon of government officials; even the sign of the overall association between corruption and economic growth seems to vary across groups of countries. ${ }^{30}$

China is an example of the complexity. In particular, some elements of corruption have speeded up the transition to private entrepreneurship by helping create a class of private capitalists, for instance, when public funds have been diverted to private individuals (asset stripping”), such as in the case of management buyouts. During the course of the reform period, corruption may therefore not have harmed economic growth, perhaps even the opposite. It has, however, contributed to serious social problems. For instance, as emphasized, for instance, by Zhang (2006), transactions in the context of existing networks have in some cases taken place at the expense of weak groups of citizens. An obvious example is the earlier mentioned expropriation of land-tenure contracts when

\footnotetext{
${ }^{30}$ See, for instance, Sleifer and Vishny (1993); Wedeman (2002); and Rock and Bonnett (2003. Indeed, the latter study finds a positive rather than a negative association between corruption and economic growth in large East Asian newly industrializing economies with stable governments.
} 
local politicians and administrators (“cadres”) turn over land-lease contracts to developers in industry, retailing, and housing. Although such interventions have speeded up the reallocation of resources from agriculture to other sectors, this has occurred at the expense of farmers' economic security. Social concerns have been relinquished for other purposes, such as a fast rate of structural change - and the enrichment of local cadres, who often share the capital gains of such reallocations of land-lease contracts. Such expropriation of agriculture land, without full compensation, is only one example of many of the misuses of powers by local cadres - other important examples being irregular payments of wages in connection with public works programs and an arbitrary imposition of levies of various types (Chow, 2006d).

Moreover, in a long-term perspective, we would expect a continuation of extensive corruption to have distinctively negative effects also on economic efficiency and growth in China. First, when the legal system improves, there is no need for having networks as a substitute for the rule of law. Second, when the transition to private ownership of firms and assets has been completed, asset stripping will no longer fulfill the function of helping create a class of private capitalists. Third, in a long-term perspective corruption is likely to contribute to social unrest, since large population groups may start questioning the legitimacy of the economic and political order. What would remain is a basically distorted allocation of resources and the risk of deficient legitimacy of the economic and political system.

There is no lack of official (in particular verbal) commitments to fight corruption in China. Indeed, China has made considerable progress in improving the legal system since the late 1970s. As a result, the legal system already seems to be more developed in China than in a number of countries outside East Asia on a similar level of economic development. ${ }^{31}$ Nevertheless, China has a long way to go in this field. ${ }^{32}$ In particular, as long as public-sector politicians and public-sector administrators have something to "sell”, such as various types of permits, corruption is difficult to wipe out. This constitutes an additional argument for further deregulation of the Chinese economy - on top of the

\footnotetext{
${ }^{31}$ See, for instance, Peerenboom (2002) and Chen (2004), and the World Bank Evaluation Index of Rule of Law (World Bank, 2005).

${ }^{32}$ For instance, according to Transparency International Corruption Perceptions Index (2005), China ranks as country 77 (among 159 countries), where the least corrupt country ranks as number one.
} 
conventional arguments in favor of improved economic efficiency. ${ }^{33}$ Such deregulation is particularly urgent if corruption starts becoming part of the culture of business and publicsector administration in a country, i.e. if social norms against corruption tend to brake down; indeed, Chow (2006d) argues that such a break down of social norms is already on the way. Presumably, quite strong legal measures against corruption would also be necessary. Moreover, international experiences and research (Svensson, 2005) suggest that independent mass media and political competition help contain corruption

How, then, should today's economic system in China be labeled? Some observers have called it "state capitalism". While this label may have been appropriate in the 1980s, it is rather misleading today, since the bulk of production, export and output (as pointed out above) have recently been taking place in privately owned firms, including foreign ones and even more so the recent expansion of these activities. The term market socialism is also misleading in the sense that dominating models of market socialism - such as those of Lange (1938) and Lerner (1934) - presuppose public ownership of firms, and in the case of Lange also government-determined prices. These models of market socialism also assumed that the government uses the price system as a method to take care of various types of externalities, including environmental degradation - a field where the Chinese authorities have not been particularly active.

For these reasons, the Chinese economic system is perhaps best characterized as a special type of "mixed economy" - with more private ownership of firms than of assets, frequent political and bureaucratic interventions in public-sector firms, poorly developed factor markets (in particular financial markets), and business networks that partly replace the "rule of law", although in many cases at the cost of widespread corruption.

Although the previous economic system in China has been overhauled by the economic reforms, there are nevertheless important continuities between the pre- and post-reform periods. Obvious examples are the inheritance of heavy industrial structures (in particular, in northern and western provinces), the collective ownership of land, the TVEs (although they have gradually been turned into private enterprises), the role of informal networks

\footnotetext{
${ }^{33}$ By way of comparison, widespread corruption in Sweden was drastically reduced in the mid-19 ${ }^{\text {th }}$ century in connection with a removal of economic regulations (including the guild system). As a result, the small class of well paid public-sector administrators had very little to "sell" to the private sector in terms of permits and regulatory concessions (Lindbeck, 1974, Chapt. 1).
} 
(the guanxi), and the combination of political centralization and administrative decentralization in the public sector.

\section{I:2 Economic Consequences}

We do not really know which specific elements of China's economic reforms during the last quarter of a century best explain the county's successful growth performance. ${ }^{34}$ We can only say that the actual combination of elements in the reform package, schematically illustrated in Figure 1, has been highly conducive to GDP growth. An important component of the reforms has then simply been to remove various institutional obstacles for economic growth, and hence release initiatives that have boosted the accumulation of real and human capital, and stimulated import of foreign technology and organization.

It is tempting, and usual, to argue that China's growth performance has also been enhanced by the gradual and experimental nature of the reform process. To a considerable extent, the process also relied on bottom-up initiatives, rather than topdown reforms, although new political signals from central political authorities have, of course, kept up the thrust of the process and influenced its course. However, the reforms do not seem to have been based on a blueprint of a specific "final stage", although new intermediate goals have been spelled out consecutively in the Five-Year Plans.

Often mentioned examples of the gradualism are that agricultural reforms began as local initiatives before they became national policies, that the reforms in manufacturing were initiated only after the success of agricultural reforms, and that the national economy was only gradually opened to international trade and foreign investment. ${ }^{35}$ As a consequence, while family farms were the most dynamic force in the Chinese economy during the first years of the reform process, the TVEs

\footnotetext{
${ }^{34}$ According to official (revised) statistics, total GDP in China is today (2005) about US\$2.3 trillion, and per capita GDP US\$ 1.700 - both measured by the official exchange rate (after the upward revision of the national accounts announced in December 2005). It is often asserted to be three or four times higher in terms of PPP calculations. Such calculations are, however, quite uncertain, not least for China (Heston, 2003).

${ }^{35}$ According to Tseng and Zebregs (2002), the tariff rate fell from well over 50 percent in the early 1980s to about 15 percent in 2002. Indeed, since a significant share of imports of goods subject to high tariffs is imported illegally, the authors argue that tariff revenues as a percentage of total imports are only 3 percent. Kanbur and Zhang (2005) report a fall in the tariff rate from about 15 to about 4 percent between 1978 and 2000.The expansion of the "special economic zones" was also gradual.
} 
generated much of the dynamism during the course of the 1980s, and foreign enterprises were an important growth factor in the 1990s. Another important example of the gradualisms is that firms and households were exposed only step-bystep to competitive markets and new price relations. ${ }^{36}$ The delay of the contraction and privatization of SOEs was also an important element of the gradualism.

It is often (realistically) argued that the gradualism mitigated tendencies to mass unemployment, as occurred in the former Soviet Union and Eastern Europe during their transitions. In other words, it is likely that the gradualist approach contributed to improve the synchronization of job destruction and job creation during a transition period. ${ }^{37}$ An obvious disadvantage was, of course, that the expansion of private (and often more efficient) firms was retarded as a result, and that reforms of financial markets were delayed. ${ }^{38}$

We cannot be sure, however, that gradualism will be equally successful in the future. First, successful reforms of factor markets, not least financial markets, often require a large number of comprehensive and complementary policy measures, including the buildup of market-supporting institutions of various types. Second, there is always a risk that a gradualist reform process will come to a stop, since gradualism gives various interest groups time to build up resistance to further changes ("veto points”). By way of comparison, recent attempts in Western Europe to gradually deregulate product and factor markets have encountered such problems.

It remains to explain why China chose such a pronouncedly gradualist approach to begin with. One reason might be that the country had recent experiences of a number of

\footnotetext{
${ }^{36}$ See, for instance, Lau, Qian and Roland (1998). In particular, "shock effects” of the price reforms were mitigated by a dual price system during a transition period, in the sense that economic agents could count on previously established prices for production volumes that had already been planned and contracted. These arrangements, however, also opened the gates for price arbitrage and corruption. ${ }^{37}$ Zhang (2004) reports that the average annual ratio of job destruction in SOEs recently has exceeded the rate of job creation only by a small margin, yielding a net employment reduction of no more than 1.4 percent per year between 1995 and 2000 and by 2.0 percent between 1999 and 2002 - according to a large sampling study.

${ }^{38}$ By emphasizing the mitigation of unemployment rather than the promotion of microeconomic efficiency, some observers, such as Godoy and Stiglitz (2006), have argued that the delay of privatization was conducive to China's transition to a market economy.

By way of comparison, developed countries have occasionally used the same technique to avoid an abrupt rise in unemployment at the time of rapid structural change, such as in connection with the contraction of coal, steel and shipyards industries in Western Europe in the 1960s and 1970s.
} 
unsuccessful "Big Bang” reforms: the radical nationalization and collectivization after the Communist take-over in the late 1940s, the Great Leap Forward 1958 to 1962, and the Cultural Revolution from the mid-1960s to the mid-1970s. Moreover, the reformers in China probably did not regard a Big Bang strategy as necessary to block a subsequent reversal of the economic reforms. Both the authorities themselves and economic agents were probably confident that the new regime would continue to be in political control for a considerable period of time. This point is important since confidence that the reforms would stay, and indeed continue, is crucial for agents contemplating investment in real and human capital. In this sense, political stability contributed to making gradualism feasible. ${ }^{39}$

The actual growth performance of the Chinese economy has been impressive regardless of whether we rely on the official figures of about 9.5 percent GDP growth per year since the start of the reforms (8.3 percent per capita), or whether we believe in somewhat more conservative calculations. ${ }^{40}$ When evaluating China's success in terms of GDP growth, it is, however, also important to take into account the resource costs of the chosen growth strategy - i.e., the efficiency of the growth path. There are several reasons to expect that the growth path has not been very efficient. One reason is the previously mentioned malfunctioning of factor markets, in particular credit and capital markets. While the financial markets in China have succeeded in intermediating the large volume of household saving to firms, the allocative efficiency of the process seems to have been poor. Obvious indicators are that the geographical mobility of capital and credit is low, that firms plow back profits rather than return them to the capital market, and that publicsector firms are favored as compared to private firms. There are also indications that the government tends to reallocate funds from regions with high returns to regions with low returns. $^{41}$

\footnotetext{
${ }^{39}$ An alternative interpretation of the gradualism would be that it was an unintended result of the political process. The experimental nature of the process suggests, however, that gradualism was quite intended. An often quoted slogan among the political leaders was that "the river should be crossed with the feet solidly touching the stones”.

${ }^{40}$ For instance, Maddison (1998 and homepage); Young (2003); and Garnaut and Song (1999) estimate that GDP growth during the reform period was about 7.5 rather than 9.5 percent per year. By contrast, official statistics on GDP growth during the last decades are, in fact, expected to be revised upwards somewhat in 2006, with a yearly growth rate since the early 1990s of slightly above 10 percent per year.

${ }^{41}$ For various indications of inefficient allocation of capital in China, see, for instance, Levine (1997);

Kahn and Senhadji (2000); Wen and Zhan (2001); and Boyreau-Debray and Wei (2005).
} 
As a result of the priorities given to state firms in financial markets, large capital-intensive firms have been favored relative to small, medium-sized and labor-intensive firms. ${ }^{42}$ Indeed, according to estimates by the People's Bank of China (2004), small and mediumsized firms received less than ten percent of the bank loans in the early $21^{\text {st }}$ century, although they produced more than half of GDP. ${ }^{43}$ There is a multitude of explanations of why the state banks favor large firms, such as lower perceived risk (because of implicit government guarantees on the loans to large firms) and political pressure from local authorities that fear severe employment problems if large firms run into financial difficulties. The alleged discrimination of SMEs in financial markets has, of course, also considerably disfavored private firms, and hence indirectly the service sector, both of which are generally regarded as disfavored also in other ways, for example by various regulations, including the allocation of land-lease contracts, building permits, etc. (World Bank, 2003b). The emergence and expansion of informal financial markets have, of course, mitigated the distortions of the allocation of resources brought about by deficiencies in formal financial markets. However, the development of informal financial markets cannot possibly have eliminated the distortions, since the duality of financial markets in itself is a distortion, reflected in different levels of interest rates.

The large resource costs of the growth path in China are also reflected in the high investment ratio, about 43 percent of GDP in recent years (“fixed capital formation”). This reflects not only the exceptionally large industrial sector (about 46 percent of GDP) but also the high capital-output ratio within that sector. ${ }^{44}$ By comparison, during similar development phases, Hong Kong, Taiwan/China, and South Korea grew nearly as fast, with smaller investment ratios (about 35 percent of GDP). The high capital intensity in China is also reflected in the relatively high marginal capital/output ratio in the interval of 4-5, while more "normal” ratios are 2.5 to $3.5 .^{45}$ The marginal capital/ output ratio has also increased during the last decade in connection with a rise in the investment share from 35 percent of GDP in the mid-1990s. It is tempting to interpret

\footnotetext{
${ }^{42}$ SMEs are defined in China as enterprises with between 8 and 2.000 employees, less than US \$ 50 million assets, and less than US \$ 37 million sales. 80 percent of these firms are estimated to have been privately owned in 2001 according to Citybank.

${ }^{43}$ For similar calculations, see McKinsey (2006, Exhibit 3.5).

${ }^{44}$ As in many other developing countries, this figure may be biased upward because statistics are likely to be more complete on investment spending than on GDP. Presumably, the revision of the national accounts reported in December 2005 has taken care of this problem, at least to some extent.

${ }^{45}$ With an investment ratio of 0.45 , the marginal capital/output ratio is 4.7 when GDP growth is 9.5 percent.
} 
this as a fall in the macroeconomic return on real investment ${ }^{46}$-- a fall to be expected when the capital stock rises extremely rapidly.

The large aggregate investment in real capital assets may be compared with the modest spending on education, which is often reported to be 4-5 percent of GDP (4.3 percent according to the OECD, 2006), of which 2.7 percentage points are financed by the public sector. ${ }^{47}$ It is unlikely that these proportions can be rationalized with reference to the relative returns on these two types of investments ${ }^{48}$. Hence, there is probably a general efficiency argument for reallocating spending from (aggregate) investment in physical assets to (aggregate) education in China, a point made, for instance, by James Heckman (2005). In principle, resources could then be freed for the consumption of both ordinary consumer goods and human services, such as health care, without jeopardizing fast GDP growth. (Today, private consumption is not more than 40 percent of GDP.) ${ }^{49}$

The modest size of the service sector is often regarded as another indicator of inefficiencies in the allocation of resources across production sectors in China. This point has recently been weakened, although not eliminated, by revisions of the national accounts (in December 2005), whereby the reported GDP share of services was raised from 32 percent to 41 percent - still, however, a fairly modest figure for a country at China's current stage of development.

Naturally, China's capital-intensive growth strategy has also constrained the ability of non-agricultural sectors to absorb the surplus labor in agriculture. This helps

\footnotetext{
${ }^{46}$ McKinsey Global Institute (2006, Exhibit 3.23) calculates that the marginal capital/output ratio has increased from 3.30 in the first half of the 1990s to 4.9 after 2001.

${ }^{47}$ Revised national accounts 2005, and UNDP (2005 Figure 3.9).

${ }^{48}$ Studies of the return on secondary and tertiary education in China in recent years, based on wage differentials, usually give returns in the interval 7-8.5 percent. A recent study by Zhang et al. (2005) concludes that the return on education has increased from 4.0 percent per year of schooling in 1988 to 10.2 percent in 2001. By contrast, a twin-study (to avoid selection bias due to innate ability) gives lower figures (Li et al., 2005), basically because of an asserted zero return on high school education, which the author asserts to function just as a device for screening ability. By contrast, one more year of collage education and vocational training is asserted to give returns of 10 and 7.3 percent, respectively. Studies based on production functions rather than wage differences suggest that the return was as high as 30-40 percent in the 1990s (Giles et al., 2003; and Fleisher and Wang, 2001). These calculations seem to have covered the return on the sum of education and on-the-job training.

${ }^{49}$ Naturally, specific investment projects in physical assets are likely to have higher returns than specific investment in human capital because of misallocations of resources within each of these investment categories.
} 
explain why the population share in agriculture is still quite large as compared to that of countries at about the same level of economic development, although the official figure, 50 percent of the population, is likely to be exaggerated. ${ }^{50}$ Indeed, the ability of non-agriculture sector to absorb the flow of labor from agriculture seems even to have diminished over time - partly as a result of the reduced vitality of the TVEs, partly as a consequence of the large lay-offs in SOEs from the mid1990s. While urban employment increased by about 5.5 percent per year in the period 1978-1993, the corresponding figure was 3 percent in the period 1993-2004 according to Kuijs and Wang (2005). Broadly speaking, we may characterize the limited ability of industry to absorb labor during the recent decades, and the related high and rising level of unemployment, as a "macroeconomic inefficiency". However, experience from other countries suggests that it is difficult to avoid this type of inefficiency during the process of rapid transition from an agricultural society to an urban society.

There are also indications of deficiencies in X-efficiency in individual SOEs in China with production inside the production possibility curves of individual firms. One indicator is huge overstaffing combined with large inventories (of intermediary as well as final goods) in many SOEs. Another indication is that many production sectors in China use several times as much energy and raw materials per output unit as the corresponding sectors in Western Europe - although this kind of inefficiency has recently decreased (Bugs, 2005; IIE, 2006, Chapt. 2). A broad indicator is that while China's GDP was about 4.4 percent of world GDP in 2004, its crude oil and coal consumption was 7.4 percent and 31 percent of the world total, respectively (People’s Daily, 2005, presenting the revised national accounts). An important explanation is that the Chinese authorities do not yet apply market principles when setting prices in resource-based industries, where the government is the dominant producer.

Moreover, there is a number of reasons to expect that state-owned firms usually are less efficient than private ones in China, including the political appointment of

\footnotetext{
${ }^{50}$ Such exaggerations are rather usual in other countries as well, since individuals registered in agriculture often also work in other sectors. In China, in particular in coastal areas, some residents who work full time in other sectors are, however, also reported to belong to the agriculture population. This seems to be the case, in particular, in newly industrialized towns.
} 
managers and the direct political intervention in the operations of such firms. ${ }^{51}$ Various studies in China have also concluded that the incentive-based contracts for managers in SOEs have often failed to reward profitability efforts - an indication of serious principle-agent problems; ${ }^{52}$ of course, similar problems can be found in other countries. It is often also believed (realistically, I think) that managers of privately owned firms are usually more concerned about boosting the work efficiency of their employees than are managers of public-sector firms. In fact, this observation is a general "folk theorem" as regards services to households, since private service providers have a stronger interest than public-sector providers that the customer are interested to come back. ${ }^{53}$ For similar reasons, we would expect that TVEs tend to be more effective when privately owned than when owned by towns and villages. This may help explain why truly collective TVEs have lost ground over time, as compared to private TVEs.

When judging the efficiency of China's growth path, it should also be kept in mind that GDP statistics represent a gross measure, since there is no deduction for capital depreciation when old buildings, infrastructure and machines are scrapped. On the contrary, work on such scrapping (for instance, demolition of houses) is included as a positive contribution to GDP. While such measurement issues emerge in all countries, they could be expected to be particularly important in China owing to the gigantic demolition of old physical structures. The hard wear and tear on the natural environment (soil, water and air) in China is another important example of capital decumulation that is not recorded in GDP statistics (indeed, not for any country). For instance, the depletion of water resources harms not only the quality of life of Chinese citizens but also the country’s production capacity in the future.

\footnotetext{
${ }^{51} \mathrm{Xu}$ et al.(2005) conclude from an empirical study that the economic efficiency of SOEs is negatively affected by more political control. Chang and Wong (2004) found that the profitability performance of listed firms in China is negatively associated with the power over decision-making in firms by local party authorities (outside intervention) relative to the managers of firms.

${ }^{52}$ See, for instance, Choe and Yin (2000). Similar explanations, in terms of principal-agent relations, for the low productivity of SOEs (as well as their profitability before its recovery from about year 2000) have been used, for instance, by Mi and Wang (2000). It remains to be seen whether the new government agency designed to manage physical government assets, the state-owned Asset Supervision and Administration Committee, will create some arm's-length distance between politicians and managers of state enterprises.

${ }^{53}$ Chow (2002, Chapt. 19) reports subjective impressions, by himself and others, of poor service in government-operated service institutions in China.
} 
So far, I have only referred to indirect evidence - "smoking guns" - of inefficiencies in the Chinese growth path. In principle, these inefficiencies should also be reflected in estimates of total factor productivity (TFP) growth in the context of aggregate production functions - although calculations of this variable are probably even more hazardous in China than in developed countries. ${ }^{54}$ Most such calculations indicate yearly rates of TFP growth in the interval 3-4 percent during the reform period. However, we may want to confine the calculation to contributions to output growth through better technology and organization in individual firms, sometimes called "multifactor productivity” (MFP) growth. In this case, it is reasonable to exclude both reallocation gains across sectors (basically shifts of labor from agriculture to other sectors) and improvement in human capital through education and training. Each of these two factors is often estimated to have contributed nearly one percentage point (per year) to the output growth rate in China during the reform period. ${ }^{55}$ When these factors are excluded from calculations of TFP growth, we obtain figures (of MFP growth) approximately in the interval of 1.5 to 2.5 percent per year during the reform period. ${ }^{56}$

Compared with the pre-reform decades, for which MFP growth seems to have been close to zero (OECD, 2005a), these figures appear to be fairly good. However, the picture requires modification in important respects. First, part of MFP growth during the reform period reflects once-and-for-all efficiency improvements in connection with the agricultural reforms in the period 1979-1984, as well as temporary productivity spurts in other sectors in the mid-1990s when prices were deregulated. Second, it would seem that much of the improvement in technology and organization in the manufacture sector, so far, is the result of the entry and expansion of non-mainland firms rather than improvements in a broad spectrum of domestic firms (Tseng and Zebregs, 2002; OECD, 2002, pp. 195-230). ${ }^{57}$ Some

\footnotetext{
${ }^{54}$ Indeed, Holz (2005b, section 4a) argues that there is no stable aggregate production function for China for the reform period.

${ }^{55}$ For estimates of reallocation gains arising from the contraction of agriculture see, for instance, Borensztein and Ostry (1996); Woo (1998); and OECD (2005a, Table 1:4). Kuijs and Wang (2006b) conclude that these reallocation gains have gradually fallen in recent years; they argue that the contribution was 0.8 percentage points per year in the period 1993-2003.

${ }^{56}$ For surveys of studies of TFP and/or MFP growth, see, for instance, Heytens and Zebregs (2003); Blanchard and Giavazzi (2005); OECD (2005a); and Wu (2006).

${ }^{57}$ Whalley and Xin (2006) estimate that such firms contributed no less than 40 percent of China's GDP growth in 2003 and 2004.
} 
studies also suggest that the rate of TFP and MFP growth has gone down during the last decade, although it is impossible to know if this new trend will continue and, if so, how strong it will be. ${ }^{58}$ While we would expect falling returns on real investment, other factors are likely to have positive effects on GDP growth, such as the faster restructuring and privatization of the SOEs, the gradually higher R\&D spending (starting from a low level), increased competition as a result of joining the WTO, and better economic integration of various geographical areas within China itself.

On the basis of existing evidence, it is reasonable to conclude that (except mainly for the sector of foreign firms) economic growth in China has largely been resource extensive in the sense of heavily relying on capital accumulation, inputs of raw materials and energy, and the depletion of environmental resources.

Naturally, both the public discussion and the scholarly literature have emphasized the huge regional differences in per capita income growth - with the eastern (coastal) provinces as the leaders, and the mountainous provinces in the west, along with the "rustbelt" areas in the north as the laggards; see, for instance, Démurger et al. (2002). Official statistics suggest that while GDP has grown by about 11.5 percent per year during the reform period in the most successful provinces (Fujian, Guangdong, Jiangsu and Zhejiang), the growth rate has been about half of that in the least successful province (Quinghai); see, for instance, Wei and Liu (2004). However, such extreme comparisons give an exaggerated picture of the overall dispersion of the distribution of growth rates across provinces. The standard deviation of the per capita growth rate across provinces during the period 1980-2002 seems to have been 1.5 percentage point, which, however, is enough to generate large differences in levels of per capita income across provinces. ${ }^{59}$ The level of per capita GDP is currently reported to be about seven times higher in the most developed than in the least developed province, even if we exclude the very poorest province (Guizhou).

\footnotetext{
${ }^{58}$ For instance, OECD (2005a, Table 1.4) reports a fall in multifactor productivity growth from 3.4 percent per year during 1993-1998 to 1.3 percent per year during 1998-2003. Angang and Zheng (2004) report a fall from 3.7 percent during 1991-95 to 0.6 percent during 1996-2001.

${ }_{59}$ According to Blanchard and Giavazzi (2005, p. 6), the standard deviation of the level of income per capita across provinces increased by 72 percent between 1998 and 2003.
} 
Indeed, the regional differences among China's provinces (and large cities) are so large that China looks like a continent with a mixture of emerging industrial countries and some of the poorest "countries" in the world. It is also well known that per capita income differs drastically between urban and rural areas within provinces. For instance, official statistics suggest that the ratio of average income in urban areas is about three times (3.3) as high as in rural areas. However, this is a highly uncertain figure because it may not fully reflect differences in costs of living in rural and urban areas - a measurement defect that is usual in other countries as well. Although average income and consumption have increased rapidly in nearly all parts of the country during the reform period (Chow, 2006a; Ravallion and Chen, 2006), these geographical differences are an important background for widespread dissatisfaction with the social situation in the country - an issue to which I now turn. 


\section{Social Advance and Regress}

The Chinese authorities have been much less active, and much less successful, in the social field than in the case of growth-promoting economic reforms. This contrasts with the pre-reform period. While aggregate output growth then was modes, and total factor productivity hardly increased at all, there were important achievements in some social fields. The main examples are basic health and elementary education - although the authorities during this period also were responsible for the devastating famine in connection with the "Great Leap Forward” in the late 1950s and early 1960s and the educational regress during the "Cultural Revolution” in the late 1960s and early 1970s.

What, then, have been the most important social developments in China during the period of economic reform? And what are the consequences of the economic reforms for the functioning of previously established (“inherited”) social arrangements? I start with the second question.

\section{II:1. Consequences for Inherited Social Arrangements}

Even to a larger extent than in the Soviet Union and the socialist countries in Eastern Europe, social arrangements in China during the first decades after World War II were organized by work units (danwei). ${ }^{60}$ For the workforce, the job guarantee was probably the most important component of income security. The compressed distribution of wages, although largely motivated on ideological grounds, added to income security, since not only the economic reward for success but also the economic punishment for failure was quite limited. In urban areas, work units also provided pensions and various cash benefits, as well as "human services”, such as basic education, health care, housing, kindergartens, and recreation facilities - indeed even barber shops. In other words, in addition to serving as executors of centrally assigned production and investment tasks, work units functioned as mini-welfare states. In a typical Chinese formulation, they were "enterprises running

\footnotetext{
${ }^{60}$ For a brief survey of social arrangements in China prior to the economic reforms see, for instance, Guan (2000).
} 
small societies” (Xiaoyi, 1996). ${ }^{61}$ Besides these arrangements by firms, public-sector authorities provided social assistance and care to some of the urban three no's (individuals with no working ability, no family, and no income).

Although both cash benefits and publicly provided human services were much less prevalent and generous in rural areas, agricultural communes did provide both job guarantees (with job obligations) and some arrangements for basic sanitation, simple health care (largely by "barefoot doctors”) and elementary education. Moreover, under the so-called wu bao hu system, rural collective organizations provided some benefits and care also for elderly and disabled individuals without family support.

Since government authorities during this period were responsible for major production and investment decisions (a rough type of input-output planning) we may, with some overstatement, say that the division of tasks between the government and the work units in China was just about the reverse of the corresponding division in developed countries today, where firms are in charge of production and investment, and the government (particularly in Western Europe) runs most of the social arrangements.

Before the economic reforms, the budgets of individual SOEs were to a considerable extent integrated with the government budget: the surpluses (profits) of individual firms were delivered to the central government budget, and the government covered their losses. Some of the social costs borne by individual SOEs were therefore pooled across the nation as a whole. Thus, the financing of the social arrangements in urban areas formally resembled high (close to 100 percent) profit taxes with “full loss-offset”. However, wages were kept down to generate sufficiently high profits to finance these social benefits. It may therefore be more appropriate to say that the financing of social spending in urban areas, in fact, was largely equivalent to payroll taxes with the incidence on wage earners. $^{62}$

It is easy to understand why the economic reforms rendered these social arrangements dysfunctional. Benefits tied to specific work units simply do not sit well in a market

\footnotetext{
${ }^{61}$ There is an obvious parallel with the social role of some large firms in small towns ("company towns”) during the early industrialization period in today's developed countries.

${ }^{62}$ Before the economic reforms, the social costs of firms seem to have been about the same size as the wage bill; see Hussain, 2000a, p. 70.
} 
economy, since an efficiently functioning labor market requires social benefits to be portable. At the same time, the market risks increased for employees as a result of recurrent structural changes and related job losses. New high-risk economic agents, such as private entrepreneurs and the self-employed, also emerged. Moreover, while the previous agricultural communes, many of which comprised thousands of households, could achieve some pooling of income risk, family farms cannot easily do so - at the same time as new market risks emerged for the farm population as well.

During an early phase of the reform period, the decline in firms' financial surplus also made it difficult for many of them to live up to their social responsibilities. ${ }^{63}$ In Chinese parlance, work units "no longer guarantee either the iron rice bowl or the iron chair" (Warner and Zhu, 2000) - a formulation referring to the fact that firms were no longer able to take responsibility for either income or jobs. Ad hoc selective subsidies and soft loans to state-owned firms with financial problems functioned as a "stop-gap solution" to the problem. In other words, loans by state banks have to some extent functioned as a substitute for traditional social policies. As a result, the discrimination of private firms in credit and capital markets was accentuated, which further reduced their ability to expand production and employment. The "double bind" - state firms constrained in shedding labor, and private firms constrained in acquiring loans - has entailed a kind of catch-22 situation during much of the reform period. It is difficult to remove this "double bind" until non-state firms can expand their employment sufficiently to absorb a much larger fraction of the redundant labor force, and before a more comprehensive system of income security is in place. ${ }^{64}$

Inadvertently, households have also helped finance firms’ social obligations, since households' deposits in state banks (at low, and during some periods even negative, real interest rates) have been intermediated into loans to state firms. As a result, the social

\footnotetext{
${ }^{63}$ According to official statistics, the financial surplus is reported to have fallen from about 20 percent of firms' aggregate revenues in 1978 to about 4 percent in 2003 (Chinese Statistical Yearbook, 1996 and 2004). There has, however, probably been a substantial recovery of these surpluses from about year 2000; see, for instance the survey of papers on this issue in The Economist, 2006, October 21. Agarwala (2004) has argued that statistics of surpluses (or profits) in Chinese firms are not fully comparable with statistics in western countries, largely because investment spending in China is not periodized in the same way.

${ }^{64}$ Although the employment level in the non-state sector in urban areas has increased considerably, from 12 to 43 million between 1990 and 2003 (Chinese Statistical Yearbook, 1990-2004), this has clearly not been sufficient to absorb redundant workers in state-owned firms and collective firms, new entrants into the labor force, and the flow (in particular the potential flow) of labor from agriculture.
} 
obligations of state firms have, in fact, been partly financed by an "inflation tax" on households' financial saving (although less so during years with low inflation). This, in turn, implies that much of the real return on household saving has been transferred to the beneficiaries of various social arrangements - much like a tax-financed pay-as-you-go ("paygo") system, although in this case the "tax" was imposed on the return on saving rather than on work.

Moreover, fewer and fewer workers are employed in firms with explicit social responsibilities. One reason is the lay-offs of workers in state firms (about a third of the initial work force from the peak level), another is the increased number of employees in private firms without similar social responsibilities. ${ }^{65}$ Indeed, among the 260 million regular workers in urban areas (with urban hukou status) in 2005, no more than between 110 and 150 million, or 40-60 percent, seem to be covered by social insurance arrangements (depending on which specific arrangements we have in mind).

These developments are important background factors for recent attempts to reform the social arrangements. Before I turn to China’s policy options in this field (Section III), it is, however, useful to highlight some recent social developments in the country.

\section{II:2. Social Outcomes}

Observers of the Chinese economy during the reform period agree, of course, that the eightfold increase in the general (average) income standard of households is an extraordinary social achievement during the course of just a quarter of a century. Moreover, the gradual emergence of open labor markets and product markets with equilibrating prices (hence without physical rationing) has also increased the freedom for individuals to choose type of employer, work place and consumption bundle - and, indeed, to set up a business and become an entrepreneur. Using Amartya Sen’s (1985) general terminology, individuals' “capabilities” have increased not only as a result of higher income but also as a consequence of increased freedom of choice.

The drastic reduction in "absolute poverty" is another major, although related, social achievement. Applying the conventional international poverty line for absolute poverty

\footnotetext{
${ }^{65}$ According to Zhang, 2004, more then 28 million state workers were laid off during the short period 1998-2002.
} 
(real income of approximately $\$ 1$ a day), ${ }^{66}$ the World Bank (2003a) estimates that the fraction of households living in absolute poverty in China has fallen from about 50 percent in 1981 to about 7 percent in 2002. This implies a reduction in the number of individuals in absolute poverty by about 400 million during the reform period. If the poverty line is instead drawn at about $\$ 2$ a day, ${ }^{67}$ the reduction is from about 88 to about 45 percent of the population - thereby illustrating the obvious fact that China is still a country with widespread poverty.

Against the background of China's fast GDP growth, the reduction in absolute poverty is no mystery. However, international experience shows that there is not always a tight relation between aggregate economic growth and the incidence of poverty (Sen, 1985; Bardhan, 1996; Islam, 1990; Lipton and Ravallion, 1995). ${ }^{68}$ In particular, the sector composition of growth is important. An illustration is that nearly half of the decline in absolute poverty in China (by the one-dollar definition) took place in the early 1980s, basically as a result of the increased productivity, and the improved terms of trade, for agriculture in connection with the shift from collective farms to family farms. Indeed, Ravallion and Chen (2006) calculate that 75-80 percent of the drop in national poverty incidence since the beginning of the reform period is a result of the reduction in poverty among the rural population. ${ }^{69}$

It is, however, also well known that relative poverty has increased from the mid-1980, in the sense that per capita income of the poorest sections of the population has increased less than the income of other groups. Indeed, the economic situation of the shrinking group of individuals remaining in severe poverty seems to have improved only modestly. For instance, according to Ravallion and Chen (2003), the mean growth rate for the poorest decile during the 1990s was only 3.6 percent, while per capita GDP growth was above 8 percent. As a result, while the poorest 10 percent of households earned 2 percent

\footnotetext{
${ }^{66}$ US \$ 1.08 a day in 1993 PPP.

${ }^{67}$ US \$ 2.15 a day in 1993 PPP.

68 Time-series regressions reported by the World Bank (2001, pp.17-18) suggest that each additional percentage point of nationwide growth in per capita GDP in China has been associated with a fall in the fraction of individuals living in absolute poverty in rural areas by 0.8 percentage points during the 1990s (one-variable regression). Cross-provincial regression indicates an even stronger relation: 1.8 percentage points. Rather similar results are recorded by Ravallion and Chen (2004).

${ }^{69}$ Fan, Zhang and Zhan (2004) have hypothesized that the heavy infrastructure investment in interior regions over several decades prior to the economic reforms finally paid off in terms of higher productivity in the agricultural sector, when economic incentives in that sector were drastically improved by the shift to family farms.
} 
of aggregate disposable household income in 2001, the richest 10 percent earned 35 percent (World Development Indicators, 2006).

This rise in relative poverty should, of course, be seen in the context of the widening of the overall dispersion of income distribution in China during the reform period; see, for instance, Renwei (2000). According to the World Bank (2003a, 2004), the Gini coefficient of per capita household income in China increased from 0.28 in 1981 to 0.32 in 1990, and to 0.43 in 2001; several other studies give similar results. ${ }^{70}$ It is well known that increased income gaps across provinces and (from the mid-1980s) also between urban and rural areas have contributed to this development. ${ }^{71}$ In the words of Zhang et al. (2001), China's provinces have developed into so-called "income clubs"- with rich clubs in the eastern (coastal) regions, middle-income clubs in the center, and poor clubs in the western (highland) regions.

While the relative per capita income gap between urban and rural areas fell in the early 1980s in connection with the agricultural reforms, the relative gap seems today to be approximately back at the pre-reform level, if the different price trends in urban and rural areas are properly taken into account (UNDP, 2005; Ravallion and Chen, 2006). The generally accepted assessment among observers seems to be that in 2003, per capita disposable income in urban areas was more than three times (3.3 times) higher than per capita net income (an approximation for disposable income) in rural areas ${ }^{72}$ - four times higher if the provision of human services were included in the calculations (UNDP, 2005). ${ }^{73}$ An important background factor is, of course, that labor productivity is about 5 times as high in manufacture and services as in agriculture (an average for industry and services). ${ }^{74}$

\footnotetext{
${ }^{70}$ See UNDP (2005, Figure 2.5 and Table 2.2). Ravallion and Chen (2006, Table 10) argue that the Gini coefficient is somewhat lower after adjustment for cost of living differences between urban and rural areas: 0.40 rather than 0.45 (in 2002) without such adjustment.

${ }^{71}$ For instance, Kanbur and Zhang (2005) report that the Gini coefficient for the distribution of average income across provinces rose from 0.29 in 1978 to 0.37 in 2000.

${ }^{72}$ Around 1990, the ratio seems to have been just above 2 .

${ }^{73}$ Indeed, it seems that about two-fifths of income inequality in the country as a whole in 2002 could be accounted for by the urban-rural income gap, decomposing the Theil inequality index (UNDP, 2005).

${ }^{74}$ Kuijs and Wang (2005) assert that labor productivity is about 3.5 times as high in services as in agriculture, and about 9 times as high in industry. Holz (2005b, Fig. 1) presents even higher figures for industry (14 times higher).
} 
In general, an increase in the dispersion of the distribution of income in the early phases of economic modernization is not unusual - and is often described in terms of movements along the upward-sloping section of the "Kuznetz curve". This is often assumed to reflect the distributional consequences of the emergence and expansion of a high-productivity, modern sector of firms alongside traditional low-productivity production units. ${ }^{75}$ When trying to explain the rise in income inequality in China, we have to add that the modernization process took place simultaneously with a shift to an economic system that relies, much more than the previous one, on economic incentives. It should, however, be added that the increased reliance on economic incentives in agriculture in the late 1970s and early 1980s, for a while actually contributed to reduce the relative income gap in the country - not only between urban and rural areas but also across households in the country as a whole. This illustrates the obvious but important point that the relation between economic growth and income inequality depends critically on the sector composition of aggregate economic growth. Similarly, the distributional consequences of increased reliance on economic incentives depend on which population groups actually experience such an increase.

Specific policy measures have also contributed to increase the income gaps during the reform period. For instance, income differences across provinces were accentuated by the opening up of the country to foreign trade and investment in the mid-1980s, since this released the (potential) absolute and comparative advantage of coastal (eastern) provinces with relatively good locations for such activities. The differential effects of these policies across provinces were accentuated by the selective opening of the country to the outside world, as well as the favoring of these areas as regards the allocation of infrastructure investment. $^{76}$

The distribution of income has become more uneven also within provinces, rural areas and urban areas. According to a study by the Chinese Academy of Social Sciences (2002), the emergence and increase of entrepreneurial income has contributed to this development in

\footnotetext{
${ }^{75}$ As often pointed out, however, South Korea and Taiwan/China experienced rapid economic growth during several decades without much (if any) widening of the overall distribution of income (Maddison, 2003).

${ }^{76}$ According to Jones et al. (2003), areas enjoying status as Special Economic Zones grew by 5 percentage points faster per year than the average for provinces.
} 
both rural and urban areas. ${ }^{77}$ So have also the cuts in central government subsidies of basic consumer goods, such as food and clothing. However, in other respects the proximate sources behind the more uneven distribution differ between urban and rural areas. ${ }^{78}$ According to the Academy, the increased share of wage income in total income in rural areas has increased the dispersion of total income in these areas, because wage income is found to be less important for poor households than for other households. By contrast, changes in the distribution of wage income are found to have been the dominant explanation for the increased dispersion of income in urban areas. One important factor behind the latter development seems to be the huge increase in the wage gap across skill groups $^{79}$, reflecting an increased return on investment in human capital since the late 1980s (Zhang et al., 2005). The softening of the hukou system also helps explain the widening of the dispersion of wages in urban areas, since the supply of low-skilled labor thereby has been boosted in these areas. The rise in unemployment in urban areas - today unofficially often estimated at 8-11 percent ${ }^{80}$ - has, of course, also contributed to widen the income gaps.

The distribution of wealth is also rather uneven in China as compared to, for instance, other Asian countries (Nolan, 2004, Chapt. 1). ${ }^{81}$ One plausible explanation is the absence of small and medium-sized private ownership of farmland. ${ }^{82}$ Thus, although the egalitarian distribution of land-tenure contracts helped disperse the rapidly rising earnings in agriculture in connection with the agricultural reforms in the late 1970s and early 1980s, the absence of private ownership of land has delayed the emergence of a large middle class of wealth holders (if we do not include the capital value of tenure contracts in the definition of wealth). "Asset stripping” in connection with privatization, as well as various forms of corruption, have presumably also contributed to make the distribution of

\footnotetext{
${ }^{77}$ Indeed, Benjamain et al. (2005) argues that the increase in rural inequality is largely a result of the emergence and increase in highly unequal earnings from family-run businesses.

${ }^{78}$ According to UNDP (2005, pp. 27-31) the Gini coefficient of the distribution of household income increased from 0.22 to 0.37 in rural areas and from 0.17 to 0.34 in urban areas between 1978 and 2002 .

${ }^{79}$ According to Blanchard and Giavazzi (2005), the skilled-unskilled wage ratio has risen from 1.3 in 1994 to 2.1 in 2003.

${ }^{80}$ The higher figure is found in a study by Giles et al. (2005), and the lower in, for instance, The Economist, Sept. 11, 2004, p.55 (based on calculations by the National Bureau of Statistics in China, and Hu Angang, Tsinghua University).

${ }^{81}$ According to McKinsey Global Institute (2006, Exhibit 3.18), less than 2 percent of the households accounted for more than 60 percent of liquid financial assets in 2003.

${ }^{82}$ Of course, if the imputed capital value of land-lease contracts were included in household wealth, the distribution of wealth would seem more even. Indeed, with this definition of wealth, the Gini coefficient for the distribution of wealth would be only slightly above the Gini coefficient for income (UNDP, 2005, pp. 31-37, based on a study of household surveys by the Chinese Academy of Social Sciences, 2002).
} 
wealth uneven. The way in which the housing stock was privatized also contributed, to begin with, to making the distribution of wealth more uneven, since housing was often sold at prices below market values to groups of citizens with income and wealth above the average - another example of "asset stripping”. However, in recent years, as the ownership of housing has gradually broadened, the distribution of housing wealth has tended to become somewhat more even (UNDP, 2005).

It is not self-evident that the income and wealth gaps will continue to widen in the upcoming decades. One reason is that the modernization of production is likely to spread across firms and across regions, so that China may begin to slide along the downwardsloping (rather than the upward-sloping) section of the Kuznetz curve. Indeed, already today, there is a tendency for the modernization process to spread to a number of interior provinces (Agarwala, 2002), although it is unlikely that all provinces will take part in this process to the same extent. ${ }^{83}$ The future development of the overall distribution of income in the country depends also crucially on what happens to productivity in agriculture and the relative price of agriculture products - in the same way as these factors dominated the development of the distribution of income in the early 1980s. Moreover, further expansion of Chinese exports of labor-intensives products may, in itself, favor workers with modest skills, although the highly elastic supply of such labor, and perhaps also the absence of traditional labor unions, tends to dampen the positive effects on wages for lowskilled workers. ${ }^{84}$ But what will actually happen to the distribution of income in China during the coming decades depends, of course, also on what type of economic and social policies that will actually be pursued in the country - in the same way as the development of the distribution of income in recent decades partly is a result of specific policy measures during that period.

Let us turn from China's social development in terms of income and wealth and their distribution to the provision of human services, such as education and health care. China made considerable achievements in these fields already in the pre-reform period 1950-

\footnotetext{
${ }^{83}$ On the basis of their study, Brun et al. (2002) argue that the spatial spillovers have been confined to coastal regions. By contrast, Luo (2005) argues, on the basis of provincial panel data from 1978 to 1999, that there have been large spillover effects on the entire Chinese economy due to the rapid expansion of the coastal provinces, but that these spillover effects have not been strong enough to prevent a widening of regional (relative and absolute) per capita income gaps.

${ }^{84}$ For a survey of the rather ambiguous results in the literature on the distributional consequences of increased openness to international trade, see, for instance, Wei and Wu (2003).
} 
1978, as reflected in the huge fall in illiteracy and nearly a doubling of life expectancy. ${ }^{85}$ Broad education and health indicators have continued to improve during the reform period. However, the pace has slowed down considerably. Indeed, China seems to have lost some of its lead among developing countries in East Asia in these fields. In particular, China does not rank very high today among developing countries in terms of public-sector spending on education and particularly not in health care (UNESCO, 2005; World Developing Indicators, 2005).

In the case of primary school enrollment, China today seems to be on level with other countries in East Asia with about the same per capita income. However, in spite of considerable progress in education during the last half-century, only a modest fraction of today's adult population has received more than elementary schooling. ${ }^{86}$ Education is also very unevenly distributed across geographical areas and population groups. ${ }^{87}$ Therefore, there is a strong relationship between children's socio-economic background and their education. ${ }^{88}$ Girls in remote rural areas lag behind the most, especially those who belong to minority nationalities. ${ }^{89}$

These distributional problems in the field of education are largely the result of the relatively small tax financing of education in China, and a correspondingly large share of non-government (“non-budget”) financing, including payments from various organizations and out-of-pocket money from households. Non-government financing seems to account for 32-46 percent of the total spending on education, ${ }^{90}$ and according to Zhang and Kanbur (2005), private out-of-pocket money has increased from about 2 to

\footnotetext{
${ }^{85}$ The illiteracy rate fell from 80 percent in 1949 to about 32 percent by 1980 (Zhang and Kanbur, 2005). Life expectancy from birth increased from 35 years in 1945 to 68 years in 1981 (China Human Development Report, 2005).

${ }^{86}$ For instance, in 2000, 16.5 percent of the population aged 25 or older had high school training, 4.3 percent college level education, 1.4 percent bachelor's degree and 0.1 percent an advanced degree (master's or doctor's degree); see, Holz (2005b, Table 4). No more than about one percent of a relevant cohort is currently in research training; see UNESCO (2005); EU (2005); Freeman (2005).

${ }^{87}$ Adult illiteracy is about twice as high in rural as in urban areas. Moreover, for the country as a whole, illiteracy among adults is reported to be 2.6 times higher for females than for males (UNDP, 2005, p. 3). According to a World Bank report (2001), about half the boys and nearly all the girls in some of China's poorest villages do not even attend school, and they are not likely to ever achieve literacy.

${ }^{88}$ Indeed, according to the World Bank (2002, pp. 42-43), the share of children from poor families who complete basic education fell from 68 percent in 1988 to 53 percent in 1995 in non-poor regions, and from 54 percent to 42 percent in poor regions. The population census in 2000 also shows a slower improvement in educational attainment during the 1990s for ethnic minorities than for the Han majority, which constitutes $92 \%$ of the population.

${ }^{89}$ For a summary of the socioeconomic status of ethnic minorities in China, see West (2004).

${ }^{90}$ The highest figure, 45 percent, is reported by Chow and Shen (2006).
} 
about 13 percent of the total spending on education in recent decades. The latter consists largely of tuition fees, schoolbooks, transportation, and school uniforms. ${ }^{91}$

In the case of health outcomes, China is relatively successful in terms of life expectancy, but less so in terms of infant mortality (UNICEF, 2005). There is, however, general agreement that the uneven distribution of health-care services across geographical areas and population groups is a major social problem. ${ }^{92}$ Indeed, the consumption of health care seems to be at least as uneven as the distribution of income. Thus, the increased disparity of income in recent decades has carried over to the distribution of health care. The deficiencies in health care are also a significant source of economic risk for the individual, in particular among those with narrow financial margins. In some cases, a vicious circle of poor health and poor financial resources may therefore have emerged.

The low level of tax-financing of health care is, of course, an important explanation for the uneven distribution of health-care services across population groups. The nongovernment share of total expenditures on health care is reported to have increased from about 16 percent in 1980 to as much as 61 percent in 2001 - a considerable fraction paid in the form of out-of-pocket money by households (Zhang and Kanbur, 2005). The nongovernment share is much larger in the countryside than in cities: 87 percent as compared to 44 percent. Indeed, the number of health personnel in rural areas is reported to have declined by around 12 percent between 1980 and 2001 (UNDP, 2005, p. 58). One reason, in addition to the lack of government-financing, is that many barefoot doctors found it economically rewarding to move to urban areas or shift to other occupations, including agriculture.

\footnotetext{
${ }^{91}$ Some families also finance additional education for their children, for instance in the evenings, on weekends and during vacation periods - partly to enhance the competitiveness of their children when applying to institutions for tertiary education. Some relatively affluent farmers also send their children to schools in urban areas.

${ }^{92}$ Although about 57 percent of the current population live in rural areas today, according to Chow (2006b) only about 20 percent of medical resources have in recent years been allocated to these areas. According to a calculation by Pei (2006, p. 173) rural residents receive only one-third of the health care per person of the urban population.

Only 27 percent of government subsidies to health-care provision are allotted to "township health centers", even though these centers are supposed to cover 43 percent of the population (World Bank, 2003a). Moreover, while households in urban areas seem to spend 6-7 percent of their income on health care, the corresponding figure for households in rural areas is reported to be 2-3 percent (preliminary estimates by Lindelöw and Wagstaff, 2005). In both areas, however, poor individuals feel compelled to spend a larger share of their income than the non-poor on such services (8-9 percent of their income in urban and 6-7 percent in rural areas.)
} 
The uneven availability and affordability of health-care resources across geographical areas is also reflected in various health indicators, such as life expectancy, infant mortality, maternity mortality rates and underweight among children in different areas of the country. ${ }^{93}$ Indeed, in some especially poor rural areas in the west and north, the health status does not seem any better than in some of the most impoverished regions in the world. In the poorest Chinese villages, there is still a high incidence of various types of infectious and endemic diseases, including chronic worm infections (World Bank, 2001). At the same time, in certain other areas, such as in the Shanghai region, both health care and health status is approaching the standard of developed countries.

An important background factor for the huge regional and local variation in both education and health is, of course, that the per capita tax base varies dramatically across villages and municipalities. ${ }^{94}$ The inter-government money flows sent down from the central authorities to lower government levels partially compensate poor local governments for their limited powers of taxation. The compensation is quite modest, however. On their way down to local governments a considerable fraction of these money flows tend to be siphoned off - in more or less the same way as some Chinese rivers, which are full of water inland, turn out to be nearly dry when they reach the coast. As a result, transfers from the central government have not prevented an increasing gap in fiscal spending across geographical areas during the period of economic reform. ${ }^{95}$ Indeed, in some poor areas, this has resulted in a combination of relatively high taxes and deficient human services.

Summing up: when China gradually shifted to a new economic system and the old arrangements for education and (in particular) health care broke down, the authorities were slow in building up new arrangements. This is, of course, a parallel to the slowness

\footnotetext{
${ }^{93}$ For instance, in 1999, infant mortality was 37 per 1000 live births in rural areas, as compared to 11 per 1000 in urban areas; maternity mortality rates were 61 versus 33; underweight for children below five years of age was 14 versus 3 percent; and stunting rates for children under five were 20 versus 2.5 percent, respectively. While life expectancy is reported to be about 66 years in the least advanced provinces, it is 80 years in the most advanced ones (UNDP, 2005, p. 98).

${ }^{94}$ Local authorities finance most of the government spending on both education and health care. An important background factor is the administrative decentralization of financial responsibilities within the public sector initiated in the early 1980s - the principle of feng zou chi fang ("eating from separate pots”). Although some recentralization has taken place since then, the resources for providing human services still vary dramatically among provinces and municipalities.

${ }^{95}$ The distribution of per capita public spending across provinces seems to be at least as uneven as the distribution of per capita GDP, perhaps even more so (China Human Development Report, 2005, p. 75); OECD, 2005a, Fig. 4).
} 
in constructing new systems of social insurance. The social consequences - poor income security and deficient human services - are consistent with the traditional inference in microeconomic textbooks that a market economy does not automatically generate adequate arrangements in these fields. Naturally, I refer to various limitations of markets for voluntary income insurance, myopia among some individuals, and difficulties to borrow for investment in human capital; poverty (and liquidity constraints) is, of course, another reason why individuals to not acquire voluntary insurance policies or invest in human capital.

It is not clear why the Chinese authorities were so late in building up new systems of income insurance and the provision of human services, when the old systems broke down in connection with the economic reforms. We may speculate that the overriding concern for economic growth meant that other objectives were put aside, possibly since such objectives were regarded as potentially harming the growth strategy. Alternatively, the authorities did not realize that markets do not automatically solve problems in the social field.

However, the shift to a new economic system is not the only background factor for the need, and demands, to reform the social arrangements in China. Two other factors should also be emphasized, namely changes in demography and the urbanization process. Behind the recent demographic development in China, there are dramatic changes in both fertility and longevity. Broadly speaking, the fertility rate has dropped from about 6.0 immediately after World War II to about 1.5 today, and life expectancy (at birth) has increased from about 35 years to about 72 years. ${ }^{96}$ To begin with, these developments "improved" the age composition of the population in the sense that the share of individuals of working age (15-59) increased from about $53 \%$ in 1975 to about $67 \%$ today - a development often characterized by demographers as a “demographic dividend”. However, as a result of the rise in longevity, this dividend is bound to be transformed into a “demographic deficit” when the number of elderly increases substantially. ${ }^{97}$

\footnotetext{
${ }^{96}$ While the US Population Reference Bureau (PRB, 2005) reports today’s fertility rate at 1.6, The China 2000 County Population Census (All China Marketing Research Co., 2003, reports the figure at 1.3; see, for instance, the discussion in Liu (2006).

${ }^{97}$ For instance, the UNPD (2000) predicts that the population share of individuals of working age will start to fall after 2010, and return to about $53 \%$ by 2050 - the lowest predicted share at that time among
} 
Until a new comprehensive pension system and new arrangements for old-age care outside the family have been built up (which is bound to take a long time), relatives will continue to play the major part in these fields, in particular in rural areas. As a (slight) caricature of the development, demographers in China talk about the " $4-2-1$ problem": a situation when one child may be required to support and service two aged parents and four grandparents! The caricature is, of course, only meant to illustrate the likelihood of either a heavy burden for individuals of working age, or serious poverty and deficient services among a large future population of elderly citizens in the country - or, most likely, a combination of both.

Recent suggestions and tendencies to soften the "one-child policy” are probably partly a response to these threats, although they may also be a reaction to the skewed proportion between newborn boys and girls (1.18 instead of the more normal figure of around 1.03). It is, however, unlikely that a removal of the onechild policy can help the demographic situation to any considerable extent due to the rather universal relation between modernization and low fertility. Moreover, experiences from many countries suggest that it is not easy, although not impossible, for governments to boost fertility. ${ }^{98}$ Since China is "getting old before getting rich”99 , these problems will emerge at a lower per capita income level in China than in today’s developed and middle-income countries (Liu, 2006).

The situation is further complicated by the likelihood that a gradually falling share of individuals of working age will reduce per capita GDP growth. This is likely to take place both through a reduction in aggregate labor supply and through a (predicted) fall in the household saving rate. It is also likely that the aging of the population will harm the vitality of the economy, since innovation and new entrepreneurship often emerge among young cohorts.

East Asian countries except Japan. The share of the population 60 years and above is predicted (by UN, 2003) to increase from 7 percent in 1975 and 12 percent today to about 30 percent by 2050 .

${ }^{98}$ Although the drastic fall in fertility has probably been speeded up by the official one-child policy, the time path of the fertility rate in China does not differ drastically from what has happened in other East Asian countries during comparable periods of "modernization" (UNPD, 2004).

${ }^{99}$ Quotation from title of article by Tian (2004). 
The social consequences of the urbanization process are also far-reaching. In principle, it is administratively easier to build up systems of income insurance for employees in urban areas than for the farm population. Moreover, the reallocation gains in connection with urbanization expand the aggregate tax base and this helps finance both income insurance and human services. There are, however, also well known negative social consequences of urbanization. Without interventions against car traffic in cities, for example through fees on driving (congestion fees), the traffic system is bound both to be inefficient and to harm the quality of city life by way of pollution, crowding and noise. Since such policy interventions are politically easier when the car owners are still a small minority, the Chinese authorities have a political "window of opportunity" in the near future to deal with these problems. Criminality, the misuse of drugs and alcohol, and mental disorders seem to be other "unavoidable" consequences of urbanization, not least in large cities. General social policies - like income insurance and liberally provided human services have in most countries turned out not to be enough to deal with these problems. Experience suggests that highly selective (targeted) social interventions among specific groups of citizens are also necessary - although such interventions often also seem to have rather limited effects. In the case of China, it might be possible to limit various negative social consequences of urbanization by promoting the growth of small and medium-sized cities, as alternatives to ever larger mega-cities (with 10 to 50 million people). "Medium size” might then be interpreted as cities with between half a million and one or two million people.

All these social problems have recently become gradually more observed and discussed both in China and among foreign observers. The central political authorities have also recently announced ambitions to improve income security and the provision of human services, in particular in rural areas. Against this background, it is of interest to look at alternative options in future social policies in China - an issue to which I now turn. 


\section{Social Policy Options}

When discussing the possibilities for the Chinese authorities to speed up improvement in social conditions, it is useful to classify policies into three categories: (i) interventions that boost and stabilize the factor income of citizens, in particular among low-income groups; (ii) tax/transfer arrangements designed to stabilize and redistribute disposable income for given factor incomes ("income security”); and (iii) improved and more evenly distributed provision of various types of human services. Since the social arrangements (the "social system”) in China are undergoing rapid change, I concentrate on China's basic socialpolicy options rather than on details of contemporary reform proposals and policy experiments. $^{100}$

\section{III:1. Policies to Influence Factor Income}

Since broad-based poverty reduction is often regarded as an overriding social ambition, a continuation of rapid growth of GDP, and hence of aggregate factor income, is crucial for further social progress in China. After all, China is still a very poor country, with about 40 percent of the population living on less than $\$ 2$ a day. There is also a strong social case for making the growth path more efficient and intensive, since more resources could then be devoted to social purposes without much (if any) loss in GDP growth. I argued in section I:2 that this would be facilitated by more flexible and less distorted capital and labor markets, more emphasis on investment in human capital as compared to physical capital assets, and more efficiency-based prices of energy and raw materials. The latter would, or course, also benefit the damaged environment in China. Less capital-intensive production would also help mitigate unemployment and underemployment, which may be an even more serious problem in the future.

Most likely, such a change in the character of the growth path would also be facilitated by a continuation of the privatization of SOEs and a removal of lingering discrimination of private firms, small firms and firms in the service sector. Moreover, a broadening of security markets (mainly shares, bonds and bills) would mean that large state firms could rely more on such markets rather than on bank loans, which would give small and medium-sized firms, including private ones, a

\footnotetext{
${ }^{100}$ For comprehensive discussions of contemporary social policy issues in China, see, for instance, Tuan (2003) and UNDP (2005).
} 
better chance of getting bank loans. Better functioning financial markets would, however, also require new instructions to public-sector banks (not to discriminate private firms) and an improved regulatory framework for financial institutions in general. More private banks through entry and privatization would also help remove the discrimination of private firms, and hence boost the efficiency in the banking system as a whole. ${ }^{101}$

The hypothesis that such reforms would make GDP growth more intensive (less resource-demanding) is supported by the fact that the level of total factor productivity is lower in SOEs and collectively owned TVEs than in "comparable" private firms (basically firms of the same size and type of industry), including foreign firms. ${ }^{102} \mathrm{~A}$ number of recent studies also suggest that economic efficiency has tended to increase in firms after being privatized. ${ }^{103}$

From a social point of view, the distribution of factor income, and not just its level, is naturally crucial. This makes a strong case for combining general growth-promoting policies with targeted interventions to boost productivity growth in low-income regions, as well as among low-income groups of citizens regardless of where they live. ${ }^{104}$ As compared to many other types of redistributional interventions, policy measures specially designed to boost factor income among low-income groups through higher productivity have the advantage of enhancing rather than harming economic efficiency. ${ }^{105}$ Indeed, empirical studies in China indicate that targeted infrastructure investment in poor

\footnotetext{
${ }^{101}$ A McKinsey report on China (2006, p. 88) argues that a more efficient allocation of financial funds, in the form of a shift of lending from SOEs to private firms, could increase GDP byUS $\$ 259$ billion, or 13 percent, alternatively keep the same growth rate with US\$ 259 billion less investment each year - resources that could then be used for other purposes. Clearly, all such calculations are highly uncertain.

${ }^{102}$ See, for instance, empirical studies that compare SOEs and private firms by Anming et al. (2003); Xu et al. (2005) and McKinsey (2006).

${ }^{103}$ Phillips and Kunrong (2005) find that growth rates are higher in geographical areas with a smaller share of SOEs - other factors held constant. Some support for the hypothesis that collectively owned TVEs are less productive than privately owned TVEs is found in a study by Chang et al. (2003), according to which privately owned TVEs tend to generate a higher return on their assets than collectively owned TVEs, even when the latter have incentive-oriented contracts for managers.

${ }^{104}$ An example of such policy measures is the poverty reduction programs coordinated by the State Council's Leading Group for Poverty Reduction (LGPR), established in 1986.

According to Hussain (2003), the incidence of absolute poverty (less than one dollar per day) varies from 0.68 to 13.5 across cities.

105 There is, however, a risk that targeted infrastructure investment will result in serious waste, since the authorities may be tempted to neglect efficiency concerns when distributional aspects become important for investment decisions. Indeed, there are many striking examples of such consequences from other countries. The heavy government investment in infrastructure in southern Italy during many decades is a well known example.
} 
geographical areas (including investment that increases market access) tend to boost productivity considerably among firms, not least agricultural firms, in such areas. Several of these studies also indicate productivity improvements as a result of better nutrition, sanitation, basic health services and education in geographical areas with large incidence of impoverished individuals. ${ }^{106}$

While those who move to urban areas would be the most obvious winners in terms of income, some individuals remaining in the countryside would also gain as a result of diminished labor supply in such areas, as well as by remittances from family members who move to the cities. Some urban insiders would most likely lose, since the upward drift of urban wages would be mitigated; ${ }^{107}$ this development would, however, also contribute to a more even distribution of factor income in the country as a whole. Moreover, the reallocation gains could, in principle, be spread through tax-transfer programs favoring low-income groups. ${ }^{108}$

Moreover, in a similar way as the shift from collective farms to family farms in the early 1980s released potential productivity gains in agriculture, a shift to private ownership of agricultural land would be expected to do the same. Not only would farmers be encouraged to make long-term investments in the land they cultivate. It would also be easier to consolidate fragmented patches of land, with productivity improvements as a predicted result - not least through better exploitation of returns to scale, for instance, in the case of wheat, vegetables and animal products. The potential efficiency gains of consolidating land holdings are vaguely indicated by the fact that there seems to be less than half a hectare per farm in China (Zhu, 2006, p. 68). ${ }^{109}$ An end to the rationing of land-lease contracts would also help remove an important source of corruption.

\footnotetext{
${ }^{106}$ Jalan and Ravallion (2002) find that investment in both infrastructure and human capital has significantly raised the return to farmers' investment in physical assets (other factors held constant). Fan et al. (2004) present empirical evidence to the effect that investment in agricultural research, and extensions of the results of such research, has a particularly high return in poor rural areas in the north and the east. Lin (2003) reports additional empirical evidence along the same lines.

${ }^{107}$ On the basis of a computable general equilibrium (CGE) model, Whalley and Zhang (2004) find nontrivial redistibutional effects of this type as a result of an assumed removal of the hukou.

${ }^{108} \mathrm{Au}$ and Henderson (2006) have made an attempt to calculate the efficiency gains through higher labor mobility across sectors and firms within rural and urban area.

${ }^{109}$ Already full transferability of land-lease contracts would, to some extent, facilitate such consolidation. In an empirical study of China, Deininger (2003) concludes that the transferability of contracts is particularly important for economic efficiency, relative to other aspects of land-lease contracts. Wan and Cheng (2001, p.191) estimate that a consolidation of fragmented patches of land would increase labor productivity by as much as 12-17 percent, depending of the types of crops.
} 
Thus, there may be a conflict between socialist ideology with respect to land ownership, on one hand, and concern for long-term efficiency and higher per capita factor income in agriculture, on the other. Deng Xiaoping is famous for the metaphor that the color of the cat does not matter as long as it can catch mice. But when it comes to the ownership structure in agriculture, the "color" of the land still matters. However, "political economy” mechanisms also help explain the resistance among powerful interest groups to the privatization of land. After all, as mentioned above, local politicians and public-sector administrators have a strong vested interest in government ownership of land - in terms of powers as well as financial rewards (including corruption).

There may also be more pragmatic, and respectable, arguments behind the reluctance of the Chinese authorities to privatize agricultural land. One might be that the distribution of wealth could gradually become more uneven within the agricultural population, since some farmers are more able than others to consolidate their land holdings. (However, the distribution of income and wealth among the Chinese population as a whole may very well, as earlier indicated, become more even.) Another reason for the apparent reluctance to privatize agriculture land might be that an ensuing consolidation of land holdings may reduce the possibilities for migrants to urban areas to return to agriculture, after having failed in the cities: there would simply be fewer family farms to return to. This disadvantage would, however, be mitigated by the fact that private ownership of land would make it possible for elderly farmers to transform their land into cash, which would help them to financially assist family members who have not "made it" in the cities.

Moreover, like a removal of the hukou, a shift to private ownership of farmland would further boost the supply of unskilled labor in urban areas, because farming would be more rapidly rationalized. This further strengthens the case for a shift to a more labor-intensive growth strategy outside agriculture.

Some of these policies to influence the level and distribution of factor income are already underway in China. The most obvious examples are the continuation of privatization of SOEs and the gradual liberalization, and in some (mainly coastal) areas even the removal, of the hukou system. It is also possible that the discrimination of private firms in financial markets is receding. There are also recent government proposals of targeted interventions 
to boost productivity and factor income in poor geographical areas, although it is impossible to predict the future energy of the government authorities in this endeavor.

Are there then any important lessons from today's developed countries about alternative methods of redistributing factor income through policy measures? There is general agreement that improvements of sanitation, basic health care, and elementary education among low-income groups were conducive to raise factor income for these groups of citizens in today's developed countries some 100 years ago. During the course of the $19^{\text {th }}$ century, a number of governments in today's developed countries have also tried to use price regulations to redistribute factor income to low-income groups. However, these policies have been much less successful.

There is no doubt that it is possible to boost the income of tenants, at least temporarily, by rent control that keeps rents below market equilibrium. The disadvantages of such policies, however, are well known from a number of developed countries - excess demand for housing ("housing shortage”), black markets for rental contracts, deterioration in the quality of the housing stock, and a fall in housing construction (which has often induced governments to start subsidizing housing construction). After a while, such policies also have problematic distributional consequences. Individuals who happen to have direct contracts with landlords are favored at the expense of new entrants into urban housing markets. Indeed, in rent-controlled markets, personal contacts and black-market transactions tend to be the basic mechanisms for getting an apartment. Since both contacts and wealth are often even more unevenly distributed than income, rent control may very well create more problems for low-income groups than for high-income groups. Obvious losers are the young, individuals who have recently broken up from marriage or cohabitation, migrants to cities, etc. The result is a pronounced insider-outsider division also in the housing market, in addition to the insider-outsider character of the labor market. China has to some extent avoided these problems by turning a large fraction of the stock of rented apartments into condominiums with free price formation, although as earlier mentioned this transition seems initially to have favored, in particular, high-income groups. It seems, however, that rents often continue to be regulated in the remaining housing stock of publicly owned apartments. 
Agricultural price regulations have also been used extensively in many countries to redistribute and stabilize factor income. While developing countries have often used such regulation to keep down the prices of agricultural products, primarily to favor urban consumers at the expense of farmers, most developed countries have done just the opposite. There is no doubt that such policies have boosted revenues for the agricultural population, at least initially. But there are also serious problems inherent in such policies. For instance, inefficient farms will survive more easily, thereby retarding the consolidation of land holdings, and hence rationalization in the agricultural sector. There are also well-known distributional problems associated with agricultural protectionism. Since higher prices of farm products are capitalized in land prices, it becomes more expensive to acquire farmland. As a result, new farmers may not gain much from protectionist measures (after deductions for capital costs). Another distributional complication is that price supports boost factor incomes not only for poor farmers with small holdings but also - indeed in particular - for affluent farmers with large holdings (since, in contrast to small farms, they sell rather than consume most of their output). Perhaps an even more important aspect is that the redistribution of factor income in favor of the farm sector largely operates at the expense of low-income consumers outside agriculture.

Several such undesired side effects of agricultural protectionism (price support) in developed countries would, of course, emerge if similar policies were applied in China. In one important respect the effects would, however, be different: there are no marketdetermined land prices onto which higher agricultural prices would be capitalized. But the privilege of obtaining such a contract from the authorities would increase, with stronger temptations for village administrators and politicians to engage in rent seeking and related corruption when land-lease contracts are allocated.

Some undesired effects of agricultural protectionism, in particular distorted prices for consumers, could be avoided if additional support to farmers took the form of subsidies or tax concessions rather than tariffs, as was the case in the United Kingdom before it joined the EU - a so-called “low-price approach” to agricultural support. Indeed, it would seem that China at the present time is heading in this direction. In particular, farm prices have during the last decade or two increasingly converged to international levels - by contrast to several other countries in East Asia, such as Taiwan/China, Korea and Japan. 
Moreover, in recent years the central authorities have abolished or reduced a number of local fees and taxes on farmers, and have also introduced explicit production subsidies, as in the case of grain production (from 2004). ${ }^{110}$ It is not clear, however, if the basic purpose of the reductions of local taxes is to support farmers without raising food prices for consumers, or if the purpose is instead to "starve" local authorities on tax revenues, in order to force them to cut the often very high administrative costs in local administration. $^{111}$

Clearly, if China contemplates relying on price regulations in housing and agriculture in the future as tools of distribution policy, the experiences in developed countries are worth taking into consideration. This point is strengthened by the observation that it has frequently turned out to be politically difficult to remove such price controls after they have been in force for some time - even when overwhelming evidence of harmful economic and social consequences has accumulated. The political cost of removing a privilege for a specific group of citizens is often higher than the political costs of not introducing such a privilege in the first place.

Naturally, not only the level but also the stability of factor income is vital from a social point of view. This holds, in particular, for the poorest sections of the population, since their margins in terms of misery are especially narrow. Policies that smooth macroeconomic fluctuations may therefore be regarded as a first line of defense against income instability. ${ }^{112}$ So far, however, it would seem that the Chinese government has not been very active in the field of short-term macroeconomic stabilization policy. In so far as such policies have been pursued at all during the last decades, they mainly seem to have taken the form of direct quantitative regulations of investment and credit flows rather than monetary and fiscal incentives, presumably because public-sector firms have been regarded as quite insensitive to economic incentives. However, as the economic system gradually becomes more incentive-oriented, stabilization policy can rely increasingly on such incentives.

\footnotetext{
${ }^{110}$ According to OECD (2005b), total agricultural support in China today amounts to 6-8 percent of gross farm receipts.

${ }^{111}$ For instance, the Tax-for-Fee reform a few years ago (which shifted tax revenues from local governments to the central government) seems to have had this purpose; see, for instance, Luo et al. (2006).

112 On the basis of a dynamic simulation model of the Chinese macroeconomy, Zhang (2001) reports that temporary external shocks tend to reduce the growth path of the economy for a considerable period of time (several years). Of course, this is not unique for China.
} 
A successful stabilization policy is important not only because it contributes to income stability. Experiences from various countries also suggest that GDP growth may be harmed for a prolonged period of time as a result of temporary macroeconomic shocks. This experience underlines the importance, even in a long-term perspective, of a reasonably successful macroeconomic stabilization policy.

Moreover, the financial crisis in Asia in the late 1990s vividly illustrates the risk of instability of factor income as a result of instability of foreign capital movements. More specifically, this experience confirms the advantage of exercising prudence when accumulating large stocks of short-term loans in foreign currency, in particular without hedging against exchange-rate fluctuations. While the domestic financial situation in China has obvious weaknesses (exemplified by the large volumes of soft loans), the country has been more prudent regarding international financial exposure. ${ }^{113}$ One example is that China has recently run a non-trivial current account surplus in its balance of payments, another that the authorities seem determined to delay full currency convertibility on the capital account until a well-developed financial infrastructure and appropriate monetary and financial policies are in place. ${ }^{114}$

Special types of policy measures to stabilize factor income in agriculture are also potentially important from a social point of view since about half the population is still in the agricultural sector. One possibility is to opt for policy measures that encourage counter-cyclical inventory holdings of agricultural products (buffer stocks) for the purpose of stabilizing the prices of such products, and hence revenues for farmers (since the price elasticity of demand for farm products is low). However, the more the markets for Chinese agricultural products become integrated with world markets, the less useful will such programs become. Moreover, as emphasized by Blanchard and Giavazzi (2005), there may be a conflict between ambitions to boost incomes for the rural population and to allow better market-adjusted exchange rates. The reason is that an appreciation of the

\footnotetext{
${ }^{113}$ In recent years, however, China's short-term foreign debt has increased to 46 percent of the total foreign debt of 233 billion dollars by mid-2005 (China Daily, June 9, 2005).

${ }^{114}$ It is somewhat doubtful, however, whether capital controls are particularly effective today for the purpose of stabilizing foreign capital flows. Prasad et al. (2005) have instead proposed that convertibility of the yuan should be delayed until a flexible (basically floating) exchange-rate regime has been created.
} 
yuan would tend to redistribute income to the disadvantage of agriculture (because China is increasingly a price taker on markets for agricultural products).

\section{III:2 Income Transfers and Social Insurance}

In urban areas, China has recently started to build up mandatory systems of income insurance akin to social arrangements in developed countries in the west ("social insurance”), combined with elements from to the so-called "provident funds" in Singapore and Malaysia. The main programs comprise unemployment benefits, social assistance, pensions and health-care insurance (the latter will be discussed in section III:3). ${ }^{115}$ The fairly high generosity of these programs, although confined to a small part of the population, is reflected in the large social security contributions required to finance them: payroll taxes amounting to about 40 percent of the wage bill for those involved (30 percentage points being paid by the employer). ${ }^{116}$ By comparison, in today’s developed countries figures around 30 percent are more common. In a short and medium-term perspective the high payroll taxes may also have retarded the expansion of employment in manufacture, since it often takes time before such taxes are fully shifted onto correspondingly lower pre-tax wages.

We would expect that social insurance in China, as in other countries, will be designed not only to provide income smoothing and income insurance, but also to assist individuals with low life-time income, hence mitigating long-term poverty. In today’s developed countries, this is usually brought about by benefit floors in various social insurance systems, such as basic (or guaranteed) unemployment benefits, sick-pay benefits or pensions. In developed countries, social insurance often also contributes to an overall redistribution of lifetime income (across the entire distribution of income). In addition to the benefit floors, this is brought about by also having benefit ceilings, without corresponding ceilings for the contributions. Of course, since such non-actuarial arrangements weaken the link between contributions and benefits, they are bound to create implicit tax wedges, which tend to distort labor supply and investment in human capital.

\footnotetext{
${ }^{115}$ See, for instance, China's Social Security White Paper (2006) and World Bank (2003a, Section 5).

${ }^{116}$ China's Social Security White Paper, 2006.
} 
Today, unemployment insurance in China, initiated in 1986 and revised in 1999, covers about 105 million urban individuals (in 2004). ${ }^{117}$ The maximum duration is high by international comparisons, between 12 and 24 months (depending on how long premiums have been paid for a particular individual). The replacement rate (the ratio of the benefit to previous wage) is fairly generous for many "urban insiders" - both compared to income security for workers in many other developing countries and (of course) to the income level of unemployed workers not covered by the system. The OECD (2002, pp. 566-567) reports a replacement rate of about 50 percent for a large fraction of those insured, although there are also reports of lower levels (about 30 percent) for others. ${ }^{118}$

Presumably, the rationale for this relative generosity towards some urban workers is to create an acceptable substitute for the receding job guarantees by state-owned enterprises. The system may, however, run into financing problems in the future, since structural unemployment in China is likely to be high during coming decades. ${ }^{119}$ A financially and socially safer approach might have been if China, at its present stage of economic development, had chosen a less generous system for the most favored groups, and instead tried to cover a larger share of the labor force. Since unemployment insurance is difficult to extend to the farm population, for which unemployment is even difficult to define, improved crop-failure legislation, and/or improved natural-disaster relief, might be substitutes for unemployment insurance for this population.

There is also a "bottom level” safety net in urban areas in the form of means-tested social assistance, whose main component is an "urban living standard guarantee", ${ }^{120}$ with a corresponding, although much less generous, program in rural areas. Although the take-up rate for social assistance is rather low today, about a quarter of the number of eligible individuals (Social Policy Research Centre, 2002, p. 11), it may increase by receding stigmatization of living off benefits, in particular if unemployment reaches high levels for prolonged periods.

\footnotetext{
${ }^{117}$ As in most developed countries today, the benefits are (or at least will be) financed by payroll taxes on firms (two-thirds of the cost) and employees (one-third).

118 The rules require that the benefit level is set between local so-called "minimum living standard" (dibao standard) and the minimum wage (or possibly a fraction of this). According to the OECD, the benefit level is usually 120-150 percent of the minimum-standard in the province in question.

119 The OECD (2005a) reports that 7.4 million people received unemployment benefits at the end of 2003.

120 The benefit level in this system is 25-30 percent of the average income in the district, or province, where the individual lives (Tang, 1999). Today this system provides income support for about 20 million people in urban areas, and about 5 million individuals in rural areas (OECD, 2005a, p. 85).
} 
Like other social insurance systems in China, the emerging mandatory pension system mainly covers urban citizens (about 163 million participants in 2004). ${ }^{121}$ It accounts for about 80 percent of total social insurance spending, and it is responsible for 28 out of the 40 percentage points of aggregate social insurance fees. It is a two-layer system. ${ }^{122}$ The first layer consists of a strongly redistributive paygo system, amended by a (so far modest) collective buffer fund - the National Social Security Fund, established in 2000. Although the role of the collective buffer fund remains unclear, one purpose seems to be to help poor regions finance their pensions, hence compensating them for the limited geographical pooling.

A second layer is supposed to consist of a fully funded, actuarial system with individual accounts, based on earlier paid contributions, hence a system without intended (ex ante) redistribution. ${ }^{123}$ One rationale for such a tier might be that a combination of paygo and funded elements provides better risk pooling than only one of these elements in isolation, since the risk characteristics between them differ. Another rationale might be to boost the development of a broad, domestic capital market. While these two rationales for funded elements in the mandatory pension system are highly relevant for China, two other usual arguments - to raise the aggregate national saving rate and to provide a higher return on mandatory pension saving - may seem less relevant. After all, the aggregate saving rate is already exceptionally high (about 50 percent of GDP), and the fast growth rate of aggregate earnings makes the return on mandatory saving in a paygo system quite high as compared to the return on a funded system. ${ }^{124}$ However, since a fully funded system takes decades to build up, and both the saving rate and the growth rate are likely to fall

\footnotetext{
${ }^{121}$ According to a survey by the Chinese Research Center on Aging (2002), more than 70 percent of the urban elderly were covered by the new pension arrangements, while the corresponding figure in rural areas was 3 percent.

${ }^{122}$ See, for instance, OECD (2005a, pp. 187-190); and Wang, (2006, p. 10).

${ }^{123}$ While the first layer promises a pension annuity amounting to 20 percent of the average monthly wage for employees in the individual's geographic area (provided a minimum of 15 years of contributions have been paid), the pension level in the second layer can only be guessed at (Ministry of Labor and Social Security, 1998, p. 51). For a general discussion of China’s emerging pension system in urban areas, see, for instance, Song (2002); and Zhao and Xu (2002).

${ }^{124}$ Broadly speaking, saving by households and enterprises in recent years each accounted for 2/5 of aggregate saving (amounting to close to 40-45 percent of GDP), and the government for the remaining $1 / 5$ (Kuijs, 2005).
} 
in the future, this argument is not watertight. ${ }^{125}$ After all, the pension system chosen now should be designed for individuals who will be retirees many decades later.

Moreover, the long-term financial viability of the new pension system may be questioned. One reason is the combination of expected future changes in demography (the "graying" of the population) and the low pension age (formally 60 years for males and 55 for females, with an effective retirement age of only 55 for the former). This problem could, in principle, be solved through a higher effective retirement age, provided there is also a reasonably well functioning labor market for the elderly (which requires flexible wages and working hours).

A more specific Chinese problem is that contributions originally paid into the funded part of the system have, in fact, been used to finance deficits in the paygo part of the system resulting in the "problem of empty individual accounts". As a consequence, the funded part of the mandatory pension system so far looks more like a defined-contribution paygo system with "notional” rather than real accounts. ${ }^{126}$ The Chinese authorities would have basically two alternative strategies to deal with the issue of "the empty accounts". One would be to abandon the idea of funded individual accounts altogether and be satisfied with a paygo system (possibly with notional individual accounts based on previously paid contributions). The other alternative would be to "recapitalize" the funded accounts. This could, be done in different ways. One possibility would be tax-financed capital injections to the individual accounts. Another possibility, suggested by Pieter Bottelier (2002), could be to let the National Council of Social Security Fund take over the shares in a number of state firms, and instruct the Fund to sell the shares - at appropriate intervals to avoid strong negative effects on share prices. The sales revenues would then be deposited on the individual accounts in proportion to what each individual has paid (directly or indirectly through his/her employer). Two birds would then be killed in one shot: the funded system would be saved and the privatization of state-owned firms and assets would be speeded

\footnotetext{
${ }^{125}$ Some of the reasons to expect that the household saving rate will fall in the future are changes in demography (fewer individuals in working age), slower per capita income growth and the build-up of mandatory social insurance - as predicted by the life-cycle saving model; see, for instance, Modigliani and Cao (2004). Another reason is that the liquidity constraints on individual households are likely to become weaker as domestic credit markets develop.

${ }^{126}$ According to OECD (2005a, p.188), the return to individuals on these accounts has been no more than 2.4 percent per year. Some observers have hypothesized that the meager return in this system is an important explanation for the low participation as well as the evasion of paying contributions.
} 
up. A much more modest version of this idea has, in fact, already been implemented: The National Social Security Fund is entitled to receive 10 percent of the proceeds from the sales of shares in state-owned companies in connection with initial public offerings (IPOs) and new share issues.

A more general issue concerning funded government-run pension systems is whether the government should opt for government-operated or privately operated pension funds. Decentralized pension funds run by non-government agents are, of course, more consistent with the notion of a competitive market economy than either one central government-run fund or several separate government-operated funds. Governmentoperated funds always run the risk of being controlled ("high-jacked”) by politicians insisting that they should decide the portfolio policy of the funds, appoint the members of the board of the fund(s), and perhaps also appoint board members in firms where the funds have bought shares. In other words, government-operated funds may in a long-term perspective result in a basically nationalized and centralized economy.

The most promising way of significantly reducing the probability of political intervention in government-created pension funds, and hence de facto nationalization of the national economy, is to opt for a number of decentralized, non-government funds from the very beginning. The system could still be mandatory and the contributions collected by the government. Considering China's recent tradition of government ownership and political intervention in individual firms, the risk (or "hope” among some observers) that a funded, government-created pension system will result in a strongly nationalized economy is hardly less in China than in other countries.

Although China has chosen to build up a mandatory social insurance system, it seems that the government will share the responsibility for income security with firms (occupational benefits) and individual households (voluntary saving and voluntary insurance); see, for 
instance, Wong (1998, pp. 198 ff.). ${ }^{127}$ Indeed, the Chinese government also encourages voluntary organizations to help the poor via donations (“charity”). ${ }^{128}$

Let me finally turn to two country-specific problems connected with China's emerging systems of social insurance. One is that risk pooling often only takes place across limited geographic areas, such as a city or a province, which creates a high degree of fragmentation of the systems across geographical areas and sectors. A second problem is the pronounced urban bias of the new emerging social insurance system - a bias which may to some extent be seen as an inheritance from the pre-1978 reform period.

At first glance, the limited geographical domain of risk pooling may look like a trivial problem, since these domains are often more populous than many European nations. However, the composition of industries often differs strongly across geographical areas, so that the rates of payroll taxes also vary considerably across such areas. In particular, firms in areas with many unemployed or pensioners are exposed to much higher social costs than firms in other areas. For instance, payroll taxes are relatively high in regions with old industries, such as mining and steel, whereas they are relatively low in regions with new industries, such as banking, electronics and civil aviation. Thus, in spite of attempts to unify the social insurance systems across geographical areas and production sectors, economic and demographic factors have led to contributions rates that vary greatly across localities and sectors of the national economy. As a result, the social insurance system in China is highly fragmented. One consequence is that the relative competitiveness of firms is influenced in a rather arbitrary way, since local wages may not fully adjust to differences in payroll taxes. Another consequence is that variations in benefits across firms and regions limit the portability of entitlements and hence impede the emergence of a national labor market.

The most obvious problem inherent in China’s emerging new arrangements for income security is, however, the bias in favor of urban insiders. First, within urban areas, individuals with only temporary residence permits, or no permits at all, are covered to a

\footnotetext{
${ }^{127}$ By the end of 2003, about 54 million individuals were reported to have signed voluntary old-age insurance with individual accounts. The Chinese Government also experiments with economic rewards in the form of an additional pension benefit (amounting to 600 yuan per year above the age of 60) for households that effectively practice family planning.

${ }^{128}$ China's Social Security White Paper (September 7, 2004) reports that there were 28,000 such social donation centers, with aggregate donations amounting to 23 billion RMB during the period 1996-2003.
} 
very small extent, if at all. ${ }^{129}$ Second, per capita social transfers are about 10 times as large in urban as in rural areas (UNDP, 2005, p. 3). Indeed, the dispersion of per capita public-sector spending across provinces seems to have widened rather than narrowed in recent decades (UNDP, 2005, p. 25).

One rationale for concentrating the arrangements of income insurance to urban areas is simply that systems of income support are more difficult to organize and administrate in agriculture than in other sectors. Indeed, the income (partly in kind) of individual members of farm families is even difficult to assess. Another rationale might be that the need for such systems would be less urgent in rural than in urban areas, since informal transfers within families, including remittances from relatives in urban areas, might be more important in the countryside. A third rationale for confining income insurance to urban areas might be that income risk for individuals would be smaller in agriculture than in industry, where business cycles are notorious. However, the last two rationales are rather weak, since the family is a very narrow unit for risk pooling and since fluctuations in factor income are hardly smaller in agriculture than in other production sectors. ${ }^{130}$

Moreover, rationales do not constitute explanations. The latter have to be expressed in terms of the political process. One explanation why the authorities have favored urban insiders might be that these have more political clout than the rural population, possibly because the authorities are more concerned about social unrest in the cities than in the countryside. Sooner or later, however, strong political demands are likely to emerge for comprehensive arrangements of income security also among rural citizens in China. The

\footnotetext{
${ }^{129}$ According to a study by Gao et al. (2002) concerning five major cities, 74 percent of permanent urban residents were covered by pension benefits in 2000, while the corresponding figure for temporary residents was 10 percent. The corresponding figures for health insurance were 68 percent and 12 percent, respectively, for unemployment benefits 33 percent and 1 percent, and for workplace injury insurance 25 percent and 14 percent.

${ }^{130}$ A study by Jalan and Ravallion (1999) suggests, however, that such arrangements are rather limited in rural areas as well. Moreover, the need for income insurance is well established also for citizens in rural areas in China, for instance in connection with fluctuations in harvests and prices of agriculture products. This seems to be a particularly serious problem for the poorest groups of the rural population. For instance, Jalan and Ravallion (1999) report that while only 10 percent of the income shocks are passed onto current consumption in the case of individual households in the highest wealth decile in rural areas (in their sample), the corresponding figure is 40 percent for individual households in the poorest decile. Since many individuals in rural areas are tightly liquidity constrained, they may not be able to smooth consumption very much, for instance, in the event of fluctuations in agricultural output and prices. In other words, poor people often cannot afford to accumulate precautionary savings or take private insurance. Moreover, as an inheritance from the pre-reform period, there are probably rather few (formal and informal) moneylenders in the Chinese countryside specialized in loans to households as compared, for instance, to India, although the situation has been rapidly changing in recent years.
} 
increasing number of so-called "social incidents" (unrest) in the countryside (70-80,000 per year recently) could perhaps be regarded as an indication of a rise in such demands (the expropriation of land-lease contracts being another background factor). Indeed, experiments with income insurance in rural areas are already underway in a number of provinces, ${ }^{131}$ and future reforms along these lines have recently been promised by the central government, for instance, in connection with the $11^{\text {th }}$ Party Congress in early 2006.

What, then, can China learn from developed countries in the sphere of income insurance? When discussing this issue, it should be noted that in their early phases of economic development, today's rich countries relied mainly on (modest) safety nets - rather than on arrangements for income protection (i.e., benefits in some proportion to previous earnings). It was only after those countries had become rather well off, mainly after World War II, that comprehensive arrangements for income protection (social insurance) became common. ${ }^{132}$ Moreover, it was not until the 1970s that these arrangements became so generous that aggregate social transfers in Western Europe reached the interval of 20-30 percent of GDP. As a result, during the early phase of building up income security in today’s developed countries, previous informal systems of income transfer - connected with relatives, or run by so-called "friendly societies" - survived until new, more formal transfer systems had acquired solid financial and administrative bases. ${ }^{133}$

So much for lessons from the early development of income insurance among today's developed countries. Some experiences from contemporary, highly ambitious systems of income protection in these countries are also of interest for China (as well as for other developing countries). I refer, for instance, to the importance that such systems are financially robust to various types of "unfavorable” exogenous shocks, such as in demography, productivity growth and macroeconomic instability. One conceivable way of achieving this could be to make the benefits automatically contingent on the development of certain variables such as the rate of growth of the tax base, the number of

\footnotetext{
${ }^{131}$ Such experiments are underway in eleven provinces, with the explicit (ultimate) purpose of eliminating the differences in income security between urban and rural areas (China Daily, Nov. 2. 2005).

${ }^{132}$ Germany under Bismarck introduced social insurance for industrial workers earlier than other countries, and the United States built up universal social security, mainly in the form of old-age pensions as early as the mid-1930s.

${ }^{133}$ This point is developed in Lindbeck (2002).
} 
individuals above retirement age, and the number of individuals living on various benefit systems (Lindbeck, 2006). Indeed, social insurance in some developed countries is today heading in this direction. The basic idea is to relieve politicians from the necessity to take unpopular policy measures from time to time for the purpose of guaranteeing the financial sustainability of various social insurance systems.

Another lesson from developed countries is that the consequences of income-security arrangements and redistribution policies for economic efficiency and economic growth depend crucially on exactly how the arrangements are designed. Therefore, it does not make sense to ask whether there is a trade-off between income security and redistribution, on one hand, and economic efficiency and growth, on the other hand, without first specifying how the arrangements of income security are actually designed. For instance, undesired disincentives effects of the taxes required to finance such systems may be mitigated by establishing a rather tight "link" between contributions and benefits for the individual - although this naturally reduces the redistributional effects across individuals. Moral hazard in the connection with various benefit systems (such as increased leisure financed by the general tax payer) may also be mitigated by making benefits distinctly lower than the after-tax wage. Otherwise, there is a risk that individuals develop a gradually more "liberal" interpretation of their rights to live on various types of benefits, such as unemployment benefits, sickness absence pay, and early retirement benefits. Such a weakening of attitudes and social norms towards benefit dependency would accentuate the problem of moral hazard. Indeed, I have hypothesized elsewhere that contemporary welfare-state problems in several developed countries are partly due to such changes of attitudes and social norms (Lindbeck, 1995; Lindbeck, Nyberg and Weibull, 1998).

These lessons from developed countries may seem self-evident at first, but experience shows that they are not easily learned and adhered to. Contemporary experience in several countries in Western Europe also expose the political difficulties in cutting back the generosity of welfare-state arrangements even after both experts and many politicians have become convinced that existing arrangements are not sustainable. It is, therefore, important that China watches out for problems of disincentives and moral hazard in the future when expanding its social insurance system - preferably before the problems have become severe. 


\section{III:3 Human Services}

Although a number of public-sector firms, or more often their subsidiaries, still provide human services to their employees, the authorities are gradually taking over the main responsibility in this field as well, with local governments as the dominant service providers. In some urban areas, however, non-government organizations (“civil society”) have also expanded their provision of human services - a development sometimes referred to as "societization” rather than "socialization” of human services. Such developments seem to be most advanced in some of the large cities, in particular in Shanghai (Sun and Tuan, 2003).

At the present time, suggestions and promises abound for improving the volume, quality, and accessibility of human services, especially in poor areas and among disfavored population groups. It is quite obvious that a considerably more equal distribution of such services would require both more government financing and larger financial transfers from the central government to poor local governments - general grants or earmarked grants for specific services depending on the degree of paternalism of the central authorities towards lower levels of government. ${ }^{134}$ At the same time, experiences from developed countries suggest that such inter-governmental transfers may result in waste at the local government level if not combined with incentives to economize with resources (such as by cutting of bureaucracies).

At the $11^{\text {th }}$ Congress of the Communist Party in early 2006, the Chinese authorities emphasized their ambitions to speed up reforms that boost local provision of human services, in particular in rural areas. A continuation of fast GDP growth would certainly make this economically feasible in the sense that increased provision of human services will then be possible alongside a simultaneous rise in the consumption of ordinary consumer goods. Sooner or later China will, however, encounter the same types of problems in this sphere as developed countries have already experienced. One example is gradually rising relative costs of labor-intensive human services (William Baumol's "cost disease”, Baumol, 1967) - assuming (realistically) that wages in the long run tend to rise at about the same rate in the production of such services as in other sectors. As a result,

\footnotetext{
${ }^{134}$ Local authorities account for about 67 percent of public-sector spending in China, although they only collect about 48 percent of tax revenues (Jourmard and Kongsrud, 2003). According to Tsang (2002, p.13), grants from central and provincial governments to poor villages and municipalities only amounted to about one percent of GDP in 1997.
} 
taxes will have to be raised without limit as long as a country allocates a gradually rising share of the labor force to producing tax-financed services of these types (Lindbeck, 2006). Indeed, the fast rate of real wage growth in manufacturing in China will bring about such cost problems relatively soon.

Another problem, which is already apparent in China, is related to the difficulties in providing effective mechanisms for adjusting quantities and qualities of human services to consumers' needs and preferences. In particular, in countries where local governments have a monopoly on the provision of human services, the "exit option" is not available as a method for consumers to exert such influence (except possibly when an individual moves to another municipality). The "voice option”, exerted via the political system, is necessarily also rather weak, because citizens’ political influence basically refers to the entire "policy packages" offered by politicians, rather than to specific services and/or specific service providers. The voice option would be expected to be especially weak in countries without free and contestable elections. To strengthen the voice option at the local level, China has recently introduced elections of leaders of village administration in some parts of the country (and in a few townships as well). There is some evidence that this reform has increased the responsiveness of local authorities to the demands of public goods by the citizens (Luo et al., 2006). But the extent to which such reforms will actually increase the citizens' influence on the provision of human services is limited both because of the absence of competing political parties and by the fact that centrally appointed party officials (party secretaries) still have strong political powers over the local administration.

\section{A. Education and Training}

While most schools in China today are government operated, many schools are still affiliated with a firm. There is also a considerable number of schools operated by other non-government organizations or by private individuals through leasing arrangements (Chow and Shen, 2006). The emerging diversity of providers of education also seems to have increased the diversity of content and teaching methods in the country (Hannum, 1999). Indeed, this diversity may be regarded as quite consistent with China's generally experimental approach to economic and social reforms.

Before as well as after the initiation of the economic reforms, education policy in China has given priority to "Two Basics": universal compulsory education and the eradication of 
illiteracy among youth and adults. However, there are serious problems in the education system in China, in particular in poor areas. Observers seem to agree that the most pressing tasks are (i) to reduce the financial burden of schooling for low-income parents; (ii) to increase the number of students in secondary and tertiary education; and (iii) to improve the quality of education. ${ }^{135}$ These problems can certainly not be solved without a substantial increase in the GDP share of government spending on education. Indeed, the new Five-Year Plan presented in early 2006 explicitly states that government spending on education should be raised from 3 (in fact 2.7) to 4 percent of GDP. Of course, such expansion should not be seen merely as an element of social policies since it may also be justified with reference to efficiency concerns.

When considering reform and expansion of the education system in China, a number of well-known choices have to be made, with some unavoidable trade-offs. One is to determine the number of years students should follow a single track and when (and how) students should be separated according to interest and ability (dual or multiple tracks). There is much international experience to draw on in this case. For instance, there is a rather general agreement among specialists in education that an early separation of schoolchildren (as, for instance, in Germany) into different tracks (in some countries already after the fourth grade) disfavors children from homes without an academic background. It is also likely that such a system will not provide theoretical skills (such as in languages and mathematics) to a large enough fraction of the population (from an efficiency point of view). The flexibility of the allocation of labor in response to future (unknown today) changing circumstances may also be weakened by early separation.

Other countries have instead chosen a single-track system that extends through the ninth grade or even further, thereby emphasizing theoretical training that prepares a large share of a cohort of youngsters (one-third or even half) for university studies. While problems associated with early separation are then avoided, the highly heterogeneous classes of students in the upper grades in the secondary school system have made it necessary to limit intellectual ambitions in theoretical education. At the same time, students who are more fit, and have more interest, for vocational (rather than academic) training often have difficulties following such highly theoretical education, with a large drop-out rate as a

\footnotetext{
${ }^{135}$ See Ministry of Education (2004) for a brief description of various quantitative aspects of China’s education system.
} 
result. One attempted remedy has been to teach vocational skills in schools. However, this has usually not been as successful as apprenticeship arrangements in firms combined with continued part-time schooling.

Another important choice is between basic abilities (in reading, writing and mathematics) and broader and vaguer "social competence" (including preparation for citizenship and leisure activities). Several countries that have chosen the latter approach now have serious problems with deficiencies in basic abilities among students as compared to countries that have emphasized the other approach (such as Finland). Again, China is well advised to draw on these experiences. It is from this perspective interesting to notice that today's rich countries emphasized "basic skills" when they were poor 50 or 100 years back - largely for the purpose of boosting the ability of broad population groups in reading, writing and counting.

It is probably a good idea to avoid extreme solutions on both issues - concerning the separation of students as well as and the choice between basic skills and more general orientation - when China is confronted with this unavoidable trade-off.

Vocational training in China is divided among SOEs, training centers affiliated with such firms, and schools affiliated with the Ministry of Education (MOE) and, to some extent, also with the Ministry of Labor and Social Security (MOLSS). ${ }^{136}$ However, there seem to be both serious deficiencies and huge variations in quality also in this system. ${ }^{137}$ Indeed, in many cases, these deficiencies may explain why many individuals have recently chosen to finance vocational training themselves. ${ }^{138}$ When considering reforms in vocational training, China is well advised to take inspiration from the German experience with apprenticeship work at firms combined with general education at school (i.e., two days a week in school and three on the job, or vice versa). This could be accomplished without very early separation of students into a two-track system.

\footnotetext{
${ }^{136}$ See, for instance, Fleisher and Wang (2001) and Li (2004). There seem to have been nearly 11 million participants in various training centers and training programs. According to Li, 1.9 million people were enrolled in schools connected with firms by the end of 2003.

${ }^{137}$ For instance, Li (2004) reports many examples of poor supervision, considerable disorder and inefficiencies, as well as large mismatches between the demand for skills and the availability of training opportunities for different types of skills. The number of vocational schools has also fallen gradually - by at least 50 percent since the early 1990s.

${ }^{138}$ In a sample used by Li (2004), about a third of the individuals engaged in vocational training participated in programs financed mainly by out-of-pocket money.
} 
On the level of tertiary (college and university) education, the number of students is, of course, largely determined by a combination of incentives to acquire such education, and the strictness with which the slots are rationed in the admission process, which in turn depends on the capacity (resources) of the system of tertiary education. Today, the bottleneck seems to be in terms of resources, since there is fierce competition for the admission to tertiary education. Naturally, the situation may change in the future as a result of the gradual build up of the resources of tertiary education. If the (expected) economic return on tertiary education, rather than the resources at colleges and universities, would turn out to be the bottleneck (a low “college premium”), the problem could be mitigated by either allowing wider wage dispersion or reducing the progressivity of the tax system. An alternative would be to increase the per-student subsidies to university education, including cash payments to students for living expenditures - or a combination. But it is difficult (in fact impossible) to calibrate and differentiate educational subsidies across different types of education so that they provide the same relative incentives across skill groups and professions, as do larger wage differentials. From that point of view, wage differentials fulfill an important role even if the government's financial involvement in higher education is considerable.

However, to bring about broad-based recruitment of students at the tertiary level, international experiences suggest that it is important to provide student loans on reasonable terms, such as government loan guarantees - possibly with the amount of yearly amortization contingent on subsequent earnings. There is also a case for direct means-tested cash grants to students from low-income families, since they are likely to be particularly reluctant to incur debt when investing in human capital. Indeed, such targeted subsidies were quite usual in today's developed countries as late as a few decades ago. Up to a certain number of university students, there is also a general efficiency argument for subsidies for tertiary (and not only primary and secondary) education because of various externalities of having an educated labor force.

Although China today devotes only just over one (probably 1.3) percent of GDP to research and development $(R \& D)$, the rate of increase in such investments has been impressive during the last decade (the corresponding figure being 0.6 percent in 1996). Indeed, the new Five-Year Plan of 2006 has the explicit goal of raising the R\&D spending 
share of GDP to 2 percent and beyond. It is also likely that R\&D spending will be better and more extensively applied in the future, since the share of such spending financed by enterprises (rather than by the government) recently seems to have increased considerably. ${ }^{139}$ This may help explain why R\&D spending and innovation in China during the last decade have become more labor-intensive and less capital- and energyusing than earlier (Jefferson, 2005; Jefferson, Su and Zhang, 2004). ${ }^{140}$ There is, however, a large regional concentration of such spending, predominantly to eastern regions (about 70 percent of total spending) and, indeed, to four large cities (Beijing, Guangdong, Jiangsu and Shanghai). This will contribute to preserve the large regional differences in per capita GDP.

Clearly, non-mainland firms have contributed substantially to the technological and organizational progress in China in recent decades. It seems, however, that this has taken place through direct import of technology rather than through $R \& D$ activities by these firms in mainland China. ${ }^{141}$ However, non-mainland firms seem to stimulate domestic R\&D spending indirectly. ${ }^{142}$ One mechanism may be that they contribute to competitive pressure, another that they simplify the access to foreign technology for domestic firms through various types of spillovers, for which there is clear evidence. ${ }^{143}$

In spite of fast technological progress in some sectors and region, China has, of course, a long way to go with regard both to the production and the actual implementation of R\&D.

\section{B. Health Care}

As a result of the earlier mentioned stagnation of public-sector health services during the period of economic reform (section II:1) - indeed a regress in many rural areas - the

\footnotetext{
${ }^{139}$ According to Jefferson (2005), thiX Ziaoyun (2004).

${ }^{140}$ Moreover, for a vast and heterogeneous country like China, modern information and communication technology (ICT) is like manna from heaven. Indeed, China has already started to exploit this source of productivity growth. For instance, while the country's telecom system had 10 million fixed-line subscribers in 1985, there are now more than 300 million fixed lines and close to 400 million mobile phones in operation (Ljunggren, 2006). ITC opportunities could also be more efficiently exploited by opening up and allowing free (non-censored) information flows in the new information channels.

${ }^{141}$ Jefferson (2005) reports that such firms contribute no more than a quarter of total R\&D spending within mainland China.

${ }^{142} \mathrm{R} \& D$ spending intensity of domestic (mainland) firms has recently increased most quickly in industries with much foreign (non-mainland) investment (Jefferson, Su and Zhang, 2004). "In-house” R\&D activities of domestic firms also seem to be highly complementary to technology transfers (Hu et al., 2004).

${ }^{143}$ Using provincial data, Cheung and Lin (2004) report positive effects of FDI on the number of domestic patent applications in the same province. Liu (2002) finds evidence of technological spillovers of foreign firms in the Shenzhen Special Economic Zone in the period 1993-1998.
} 
private sector has taken over the responsibility for about a third of the production of such services (Kin et al., 2002). (However, some assets (medical facilities) are still owned by public-sector authorities, and rented to private agents.) In itself, this shift to private producers is not necessarily a problem. As in the case of education, and more so, the real problem is rather that the public sector has reduced and decentralized its responsibility for the financing of these services. Only about 125 million individuals in urban areas seem to have comprehensive health-care insurance today, ${ }^{144}$ and perhaps about the same number participate in modest cooperative health plans in rural areas (Chow, 2006b). This is the background of the earlier mentioned fact that private financing in China covers about 60 percent of the total health costs, usually taking the form of pocket money. The central government has, however, announced ambitions to expand the coverage both in urban and rural areas.

In spite of the weaknesses of health services, there has been a rapid increase in total health spending - today amounting to 5.3 percent of GDP, which is 2-3 percentage points higher than in countries with a similar level of per capita income in Southeast Asia (except for Vietnam). The apparent paradox of increased spending and stagnating - and in some respects even deteriorating - health services suggests inefficiencies of health care (presumably reflecting deficiencies both in the organization and in the incentive structure). An additional indicator of inefficiencies is frequent reports of moral hazard in health care, for instance, in the form of excessive health investigations of patients (Chow, 2006b) - a rather common problem in a number of countries, in particular when health care is financed by insurance.

A more specific indicator of inefficiency in the Chinese health sector is that about 68 percent of government funding was recently reported to have gone to hospitals rather than health clinics and preventive health, in spite of the fact that many experts regard the latter activities as potentially more important (on the margin) for the overall health situation (UNDP, 2000, p. 3). ${ }^{145}$ The inefficiencies in health care are also a result of the uneven

\footnotetext{
${ }^{144}$ Blumenthal and Hsiao (2005) report that the share of employees in urban areas with health insurance is 55 percent (in 2003) - a fall from 77 percent in 1993, largely a result of reduced employment in state firms and a rise in private and informal employment (UNDP, 2005, p. 65). In particularly poor areas of the country, many private doctors charge service fees simply because local governments often cannot afford to finance the services.

${ }^{145}$ Of China's total health expenditure (in 2002), 50 percent is reported to have been allotted to urban hospitals, and only 7 percent to health centers. It also appears that only about 7 percent was devoted to "public health"
} 
distribution of such services among population groups, with a concentration of health resources to large and medium-sized cities, receiving about 80 percent of the total resources (UNDP 2000, p. 3), which cannot possibly reflect the regional distribution of the need for health-care resources. Naturally, the uneven distribution of health services may also depend on differences of competence across local areas in the field of health care organization.

Another country-specific inefficiency in China is related to strict price controls on specific types of health services. This has induced hospitals and health clinics to finance much of their health-care provisions by revenues from the sale of drugs. This, in turn, has created strong incentives both to charge high prices for drugs and to over-prescribe drug medication (Hesketh and Zhu, 1997). ${ }^{146}$ Clearly, efficiency considerations require a new price system for health services with a more symmetric price system for drugs relative to other types of treatment.

Indeed, reforms are underway in health care, including announced ambitions to improve the situation in rural areas, ${ }^{147}$ although China has a particularly long way to go in these areas. ${ }^{148}$ As in the case of pensions, the financing of future health-care insurance in urban areas is supposed to rely on a combination of paygo and funding (with individual accounts), the latter organized along lines similar to Singapore and Malaysia. ${ }^{149}$ Presumably, individual accounts are particularly useful for relatively inexpensive, mainly “out-patient” treatment, rather than expensive hospital treatment. Costly treatment (including "catastrophic health care”) is supposed to be covered by the paygo (redistributive) part of the system. However, the individual accounts already seem to have run into financial difficulties (in a similar way as the pension system), thereby forcing the government to inject new money from the general budget into the paygo part of the

(preventive health care) in spite of the fact that such treatment is particularly important in poor countries (UNDP, 2005, p. 58).

${ }^{146}$ As much as half of the total spending on health care is reported to consist of costs for drugs, while more normal figures in developed countries usually are 10-15 percent (Blumenthal and Hsiao, 2005).

${ }^{147}$ See, for instance, China’s Social Security White Paper, 2004.

${ }^{148}$ By the end of 2003, about 110 million individuals in urban areas, comprising 80 million employees and 30 million retirees, were reported to have been covered by health insurance, while the coverage in rural areas was still extremely low.

${ }^{149}$ The individual's entire contribution (two percent of the earnings) and a third of the contribution covered by the employer (six percent of the wage bill) are supposed to be paid into an individual's (funded) personal account, while the remaining two thirds of the employers' premium is allotted to the paygo part of the system (i.e., the common "health insurance pool”). See, for instance, Social Insurance Research Team (2003). 
system. ${ }^{150}$ The state also encourages enterprises to establish supplementary medical insurance for their employees, mainly to settle medical expenses not covered by mandatory medical insurance.

How, then, should well-known trade-offs in health care be addressed? In the case of poor countries, both ethical and efficiency concerns make a case for emphasizing preventive health services and basic curative health services rather than sophisticated (specialized) curative health care. (Rich individuals may, of course, pay for sophisticated health care abroad, which would hardly create any impediments for the rest of the population in China.) Whereas preventive health care in developed countries is mainly an issue of individuals' life style (smoking habits, diet, exercise etc.), in poor countries it is perhaps mainly an issue of sufficient nutrition, sanitation and effort to combat infectious diseases - areas where China has been quite successful. Indeed, the deficiencies in curative health care in China have not prevented a gradual improvement in broad health indicators in China, such as higher life expectancy. Perhaps health care has stronger effects on the quality of individuals' lives than on the length of life, which may largely be determined by the earlier mentioned examples of preventive health services.

With China's rapidly ageing population, the need for institutionalized old-age care is also bound to increase. Some state-owned enterprises still finance and organize such services for their previous employees - including housing, health care, recreational activities, and even funeral arrangements. However, as in the case of other human services, these responsibilities have gradually been shifted to municipalities, in particular in urban areas (Hussain, 2000b, pp. 67-68). ${ }^{151}$ Nevertheless, as in most other countries, family members perform the bulk of old-age care. Naturally, this will become increasingly problematic when both spouses work in the open market.

The future health situation is, of course, also an issue of environmental problems such as air and water pollution. Indeed, not only research but also casual observation indicate that

\footnotetext{
${ }^{150}$ The payroll tax that finances health insurance is currently 8 percent of the wage rate (OECD, 2005, Table 4:3). Social Policy Research Centre (2002, p. 9) estimates that it would have to be considerably higher than 10 percent in the future to avoid deficits.

${ }^{151}$ There are also some developments in this direction in the countryside. An example is the attempt to follow up the traditional "five guarantees" system from the 1950s, designed to help the elderly (as well as the disabled and minors) without family support to obtain a certain minimum of food, clothing, housing, medical care, and proper burial.
} 
China's pollution problems are among the most serious in the world. Although environmental degradation does not yet show up drastically in broad health indicators, such as life expectancy and child birth, a continuation or even a further deterioration of the present situation is bound to have such effects sooner or later - as happened earlier in the Soviet Republics and Eastern Europe during the socialist period.

The costs of cleaning up the environment would be considerable, but so would the longterm benefits, including the gains in terms of improved health (Brajer and Mead, 2004). Naturally, the severe environmental problems are partly side effects of China's one-sided emphasis on capital-intensive, raw material-intensive and energy-intensive industry ${ }^{152}$ another illustration of the interaction between growth strategy and social developments. However, these problems also a result of the limited priority assigned to environmental protection as compared with production of goods and services - a historical parallel to similar neglect during the early phase of industrialization in today’s developed countries.

The Chinese authorities have recently tried to deal with the pollution problem by quantitative regulations and graduated charges when emissions exceed certain mandated ceilings. But many SOEs do not seem to be particularly sensitive to such charges, simply because profit considerations do not dominate their objectives. (This resembles the insensitivity of state firms to monetary and fiscal incentives in the context of stabilization policy.) There have been recent experiments (conducted in cooperation with the World Bank) to exert social pressure on firms, rather than simply relying on quantitative restrictions and economic incentives. ${ }^{153}$ In other words, as a complement to the latter types of policy measures, the idea seems to be that firms' pollution behavior can be influenced by social norms, which are supposed to be upheld by the general public's approval or disapproval of firms' behavior. However, in the future, when most firms in China are likely to be profit-oriented, it will be easier to pursue incentive-based environmental policies using (Pigouvian) tax/subsidy programs.

Healthy working conditions are, of course, another important aspect of preventive health care. Indeed, it is natural that citizens want to transform some of their rising living

\footnotetext{
${ }^{152}$ Industry including the building sector accounts for more than 40 percent of GDP.

${ }^{153}$ One attempted method is to rank firms (publicly) according to their degree of environmental concern - the so-called “Green Watch Program” (Wang et al., 2004).
} 
standards into a safer and more pleasant work environment - often with improved health conditions as a bonus. On this issue, however, developing countries including China face the risk that some developed countries will push for faster improvement in working conditions than the developing countries themselves (the authorities and/or citizens) would be willing to pay for. I am referring to the demands of some developed countries on inaugurating internationally mandated "social clauses", including so-called "labor standards”, in developing countries - backed by threats of trade sanctions, possibly handled by the WTO.

In comparison, latecomers in economic development among European countries in the late $19^{\text {th }}$ and early $20^{\text {th }}$ centuries (such as Finland and Sweden) did not encounter similar threats of intervention when they entered export markets with relatively low wages and poor working conditions - perhaps partly because of their small size. The absence of such protectionist backlashes certainly helped them take advantage of export-oriented economic growth.

Presumably, the best way for developing countries, including China, to fight the disguised protectionism underlying such intervention is to join forces with other developing countries in pursuit of an outward-oriented development strategy. However, in doing so, it is important to abstain from provoking protectionism in developed countries - not only by avoiding considerably undervalued currencies, but also by abstaining from abusive child labor and other labor arrangements that may be interpreted as "forced labor". 


\section{Concluding Remarks}

I have described China's economic reforms since the late 1970s as a gradual transformation of the country's economic system, expressed in terms of a nine dimensional vector (Figure 1 on page 8). I have argued that China has much to gain from a continuation of the transformation in the form of further deregulations of product and factor markets, not least the markets for capital and credit. More efficiency-based prices on energy and raw material are also important from that point of view. Deregulations and equilibrating prices would also help reduce corruption, since politicians and public-sector administrators would then have less to "sell”, such as various types of permits, loans and subsidies. Deregulations, combined with less political interventions in publicly owned firms, would also contribute to further decentralization of production and investment decisions.

The decentralization of China's economic system would be further speeded up by a continuation of privatization and by improvements in the working conditions of private entrepreneurs. Broad experience from developed countries also indicates that private entrepreneurship is highly conducive to innovations; see, for instance, Baumol (2000). Moreover, a large-scale privatization banks would, most likely, reduce the bias in bank lending in favor of state enterprises. (In the case of large state banks, China has so far only sold minority posts.) China has also much to gain from giving up its resistance to private ownership of land which, most likely, is a serious obstacle to faster income growth in agriculture (at least during a period of transition). An important source of corruption would then also be removed by taking away the control of land allocations from local caders.

Deregulation and privatization would also boost competition and increase the role of economic incentives in the production system. Although a continuation of a high degree of internationalization of the economic system is also favorable for competition, I have argued that it is not likely that such a large country as China will, in the long run, have a foreign-trade sector of the present size (i.e., about three times as large as in the United States and Japan). 
If the continued economic reforms follow such lines, it is likely that China's growth path will be more "intensive" (less resource-demanding) than earlier - with more emphasis on human relative to physical capital, less use of raw materials and energy (per output unit), and a faster introduction of new technology, innovation and organization.

Why should such "fine tuning" of the economic system be important when China has already been exceptionally successful in generating fast economic growth? One answer is that a more intensive growth path would release resources for consumption of both ordinary consumer goods and human services (such as education and health care) without reducing the GDP growth rate (much). There would also (or alternatively) be more resources available for cleaning up the highly polluted environment. Less capitalintensive production would also counteract tendencies to gradually increasing unemployment. A complementary answer to the question (of the importance of "fine tuning” of the Chinese economic system) could be that a more intensive growth path will be more decisive in the future, when China is likely to be closer to the international technological frontier in a number of fields. Extensive growth (based on the mobilization rather than the effective use of resources) was probably less problematic in early stages of the transition period. ${ }^{154}$ To quote Edmund Phelps (2005): in an early stage of economic growth, "there are so much low-hanging fruit out there in the trees ... that it doesn't matter very much which fruit you pluck".

As pointed out by many observers, the Chinese authorities have been less concerned with social than with growth-oriented policies. Naturally, I refer to the neglect of policies designed to improve income security, reduce income inequalities, and provide human services to broad population groups. When considering ways of mitigating deficiencies in these fields, policies are confronted with a delicate balance between ambitions to further the social situation for "urban insiders", on the one hand, and provide modest safety nets and human services for the population as a whole, on the other hand. In this essay, I have offered both ethical and efficiency arguments for shifting the balance in favor of the latter strategy.

\footnotetext{
${ }^{154}$ In a more general context, without specific reference to China, approximately this point has been made by, for instance, Nelson and Phelps (1966) and Acemoglu, Aghion and Zilibotti (2006).
} 
If the transformation of China's economic system followed such lines, the role of the government would become more "traditional" than today. By that I mean that the government would focus on policies to encouraging market-supporting institutions, improving the infrastructure, stimulating investment in human capital, contributing to a stable macroeconomic environment, mitigating major market failures, including those in insurance markets, taking actions against negative externalities of various types, and redistributing income in favor of poor geographical areas and population groups - rather than intervening in individual firms.

It is, however, generally realized that major improvements in the social arrangements would require much more government financing (taxes and/or mandatory insurance fees). Although tax revenues could already be increased through more efficient tax collection, considerably increased policy ambitions in the social field certainly require higher tax rates. It would also be important to reform the system of intergovernmental financial relations by transferring more funds from central to local governments, in particular in poor geographical areas.

In spite of the modest ambitions of social policies during the period of economic reforms, life expectancy and adult literacy are rather impressive in China as compared to other countries with about the same per capita GDP. Indeed, according to several cross country evaluations, China ranks higher in terms of such "social” (or "human") variables than in terms of per capita GDP - in spite of the rather low priority given to social issues during the reform period. ${ }^{155}$ There are at least two ways of explaining this apparent paradox. One could be that the high life expectancy and the widespread adult literacy are to a considerable extent an "inheritance" from the pre-reform period, when widely distributed, although quite simple, health care and basic education were emphasized. As regards health, another explanation could be that China more than other countries with a similar

\footnotetext{
${ }^{155}$ For instance, while China was ranked as country number 96 in terms of GDP per capita (measured on a PPP basis) in 2003, it was ranked as number 85 in terms of the HDI index (UNDP, 2005, p. 81). This index - the Human Development Index (HDI) is based on a number of broad economic and social indicators.

In another study, the China Center for Modernization Research (2005) concludes that China is in about the same position in terms of "economic modernization" as the most modern countries today were 100 years ago, while the lag is 80 years in terms of "social modernization". While economic modernization is then measured by variables such as GDP per capita and the share of the population and the share of GDP produced in agriculture, human modernization is measured by health variables, such as average life expectancy, and basic education variables, such as adult literacy rates.
} 
GDP per capita for a long time (before as well as after the initiation of the economic reforms) has stressed widespread sanitation and nutrition for the entire population factors that, on the margin, may have been more decisive for life expectancy than health care. Moreover, as hypothesized above, serious health effects of environmental disturbances may only occur after rather long time lags (several decades).

I have also emphasized a number of lessons from the experiences of social arrangements in today's developed countries. The most important positive lesson is perhaps that it has turned out to be possible to create both considerable income security (through mandatory social insurance) and high-quality human services for the entire population - apparently without drastic reductions in GDP growth. Since social spending and tax rates are still quite modest in China, not even considerably more ambitious social programs are likely to be very harmful to economic efficiency and economic growth. Indeed, up to a point, some social policies may even be conducive on these accounts. The most obvious examples are subsidies of investment in human capital via better education and health care, as well as infrastructure investment in poor areas with a potential for considerable productivity increases. Social insurance may also stimulate investment in human capital among poor citizens by removing liquidity constraints (Benabou, 1996; and Aghion et al., 1999). It is often also believed that, up to a point, social insurance may contribute to social stability, which may also enhance economic efficiency and growth - indeed, Bismarck’s classic argument for mandatory social insurance among workers. These examples illustrate the point that it does not make sense to ask whether there is a trade-off between welfare-state arrangements, on one hand, and economic efficiency and growth, on the other hand, without first specifying the starting point and how new social arrangements would actually be designed.

However, experiences in developed countries also show that it is important to make welfare-state arrangements reasonably robust to exogenous shocks - such as unfavorable changes in demography, productivity growth and unemployment. It us also important to avoid large “undesired” endogenous behavioral adjustments by individuals, for instance, as a result of tax distortions and moral hazard. I have discussed various ways of minimizing such risks. One is, of course, to keep the generosity of the benefits within "reasonable” limits. Another way would be to opt for "quasi-actuarial” social-insurance systems, hence tying benefits tightly to the individual's own previously paid 
contributions. Countries in early phases of building up welfare-state arrangements, including China, have particularly strong reasons to be aware of the risks of disincentive effects when entering the route towards more advanced welfare-state arrangements. By an appropriate design of future social arrangements, and their financing, China may be able to avoid serious trade-offs in the near future between social ambitions, on one hand, and efficiency/growth considerations, on the other hand. 


\section{References}

Allen, Franklin, Jun Qian and Meijun Qian, 2006, “China’s Financial Reform: Past, Present and Future”, mimeo, University of Pennsylvania, Wharton School, forthcoming in Loren Brandt and Thomas Rawski, eds., China’s Economic Transition: Origins, Mechanism, and Consequences.

Acemoglu, Daron, Philippe Aghion and Fabrizio Zilibotti, 2006, “Distance to Frontier, Selection, and Economic Growth”, Journal of the European Economic Association, 4(1), pp. 37-74.

Agarwala, Ramgopal, 2002, The Rise of China: Threat or Opportunity?, New Delhi: Bookwell.

Aghion, Philippe, Eve Caroli, and Cecilia García-Penalosa, 1999, “Inequality and Economic Growth: The Perspective of the New Growth Theories”, Journal of Economic Literature, 37, pp. 1615-1660.

Angang, Hu and Jinghai Zheng, (2004), “Why China’s TPF has Dropped”, mimeo, Center for China Studies, School of Public Policy and Management, Tsinghua University, Beijing.

Anming, Zhang, Yimin Zhang and Ronald Zhao, 2003, “A Study of the R\&D Efficiency and Productivity of Chinese firms”, Journal of Comparative Economics, 31(3), pp. 444-464.

Asian Development Bank, 2004, Asian Development Outlook, Manila.

$\mathrm{Au}$, Chun-Chung and J. Veron Henderson, 2006, “How Migration Restrictions Limit Agglomeration and Productivity in China”, Journal of Development Economics, 80, pp 350-388.

Aziz, Jahangir and Christoph Duenwald, 2002, “Growth-Financial Intermediation Nexus in China”, Working Paper WP/02/194, Washington, DC: IMF.

Bardhan, Pranab, 1996, "Research on Poverty and Development Twenty Years after Redistribution with Growth”, in Bruno, Michael and Boris Plesekovic (eds.), Annual World Bank Conference on Development Economics 1995, pp. 59-72, Washington, DC: The World Bank

Baumol, William, 1967, "Macroeconomics of Unbalanced Growth: The Anatomy of Urban Crisis”, American Economic Review, 57(3), 415-26. 
, 2000, The Free-market Innovation Machine, Princeton: Princeton

University Press.

Beijing Normal University, 2003, A Report on the Development of China's Market

Economy, Institute of Economic and Resources Management, Beijing: China

Foreign Economic Relations and Trade Publishing House.

Benabou, Roland. 1996, “Inequality and Growth”, NBER Macroeconomics Annual, 11, pp. 11-74.

Blanchard, Olivier J. and Francesco Giavazzi, 2005, "Rebalancing Growth in China: A Three-Handed Approach”, CEPR Working Paper No. 5403

Blumenthal, David and William Hsiao, 2005, "Privatization and its Discontents - The Evolving Chinese Health Care System”, New England Journal of Medicine, 353 (11), pp. 1165-1170.

Borensztein, Eduardo and Jonathan D. Ostry, 1996, “Accounting for China’s Growth Performance”, American Economic Review, 86(2), pp. 224-228.

Bottelier, Pieter, 2002, “Where is Pension Reform Going in China? Issues and Option”, Perspectives, 3(5).

Boyreau-Debray and, Genevieve and Shang-Kin Wei (2005), "Pitfalls of a State-Dominated

Financial System: The Case of China”, NBER Working Paper No. W11214, Cambridge, MA.

Brajer, Victor and Robert W. Mead, 2004, “Valuing Air Pollution Mortality in China’s Cities”, Urban Studies, 41, pp. 1567-1585.

Brun, Jean-François, Jean-Louis Comes and Mary-Françoise Renard, 2002, “Are there Spillover Effects between Coastal and Non-Coastal Regions in China?”, China Economic Review, 13(2-3), pp. 161-169.

Bugs, Heiko, 2005, “Cost Comparison for Manufacturing - China and India”. Paper presented at Conference on “China, and Indian Opportunity” in Bangalore and Hyderabad, India.

Cao, Cong, 2004, “Challenges for Technological Development in China’s Industry, Foreign Investors are the Main Providers of Technology”, China Perspectives, No. 54, pp. 4-16.

Chang, Chun, Brian P. McCall and Yijiang Wang (2003), “Incentive Contracting versus Ownership Reforms: Evidence from China’s Township and Village Enterprises”, Journal of Comparative Economics, 31(3), pp. 414-428. 
Chang, Eric C. and Sonia M. L. Wong, 2004, "Political Control and Performance in China’s Listed Firms”, Journal of Comparative Economics, 32, pp. 617-636.

Chen, Albert, 2004, An Introduction to the Legal System of the People's Republic of China, $3^{\text {rd }}$ ed., Hong Kong: LexisNexis-Butterworths.

Cheung, Kui-yin and Ping Lin, 2004, "Spillover Effects of FDI on Innovation in China: Evidence from the Provincial Data”, China Economic Review, 15(1), pp. 25-44. China Center for Modernization Research, 2005, China Modernization Report - A Study on Economic Modernization, Beijing: Chinese Academy of Sciences, May 19.

China Compendium of Statistics 1949-2004, 2005, National Bureau of Statistics Beijing: China Statistics Press.

China Daily, 2005, June 9, Nov. 2. chinadaily.com.cn/english/doc.

China Human Development Report, 2005, China Development Research Foundation, Beijing.

China's Social Security White Paper, September 7, 2004, The Decision on Establishing a Basic Medical Insurance System for Urban Employees.

China’s Social Security White Paper, 2006, China Internet Information Center, webmaster@china.org.cn

China Statistical Yearbook, different years, National Bureau of Statistics, Beijing: China Statistics Press.

Chinese Academy of Social Sciences (CASS), 2002, Beijing.

Chinese Research Center on Aging, 2002, Beijing.

Choe, Chongwoo and Xiangkang Yin, 2000, “Contract Management Responsibility System and Profit Incentives in China’s State-owned Enterprises”, China Economic Review, 11 , pp. 98-112.

Chow, Gregory C., 1997, “Challenges of China’s Economic System for Economic Theory”, American Economic Review, 87, pp. 321-27.

, 2002, China’s Economic Transformation, Oxford: Blackwell Publishing. , 2006a, “Rural Poverty in China: Problems and Solutions”, mimeo, paper presented at the meeting of the Chinese Economists Society, Shanghai, July 1-2. , 2006b, “An Economic Analysis of Health Care in China”, mimeo, 5/27/06, Princeton. -, 2006c, “Globalization and China’s Economic Development”, mimeo, Princeton University. 
2006d, “Corruption and China’s Economic reform in the Early $21^{\text {st }}$ Century”, International Journal of Business, 11(3).

Chow, Gregory C. and Yan Shen, 2006, ”Demand for Education in China”, mimeo, January, 2006, Princeton University.

Cook, Sarah, 2000, “Readjusting Labour: Enterprise Restructuring, Social Consequences and Policy Responses in Urban China”, in Warner, Malcolm (ed.) op. cit.

Deininger, Klaus, 2003, “The Impact of Property Rights on Household’s Investment, Risk Coping, and Policy Preferences: Evidence from China”, Economic Development and Cultural Change, 51, pp. 851-882.

Démurger, Sylvie, Jeffrey D. Sachs, Wing Thye Woo, Shuming Bao, Gene Chang and Andrew Mellinger, 2002, “Geography, Economic Policy, and Regional Development in China”, NBER Working Paper No. 8897, Cambridge, MA.

Dobson, Wendy, 2006, "Financial Systems in China and India: A comparative Analysis, International Conference on the Dragon and the Elephant: China and India's Economic Reforms, July 1-2, Shanghai.

Dong, Ziao-yuan, and Lixin Colin Zu, 2006, “Labor Restructuring in China’s Industrial Sector: Towards a Functioning Urban Labor Market”, mimeo, presented at conference by China's Economists Society conference in Shanghai, July 1-3.

EU, 2005, Key Figures 2005 on Science, Technology and Innovation. Towards a European Knowledge Area, document prepared by Vincent Duchene and Emmanuel Hassan, July.

Fan, Shenggen, Linxiu Zhang, and Xiaobo Zhang, 2004, ”Reform, Investment and Poverty in Rural China”, Economic Development and Culture Change, X, pp. 395-421.

Fleisher, Belton and Ziaojun Wang, 2001, "Skill Differentials, Return to Schooling, and Market Segmentation in a Transition Economy: The Case of Mainland China”, Journal of Development Economics 73(1), pp. 315-328.

Freeman, Richard B., 2005, “Does Globalization of the Scientific/Engineering Workforce Threaten US Economic Leadership”, NBER Working Paper No. 11457, Cambridge, MA.

Garnaut , Ross and Ligang Song , (eds.), 1999, China: Twenty Years of Economic Reform, Canberra: Asia Pacific Press.

Gao, Jun, Juncheng Qian, Shenglan Tang, Bo Eriksson and Erik Blas, 2002, "Health Equity in Transition from Planned to Market Economy in China”, Health Policy and Planning, 17 (Suppl. 1), pp. 20-29. 
Giles, John, Emily Hannum, Albert Park and Juwei Zhang, 2003, “Life-Skills, Schooling, and the Labor Market in Urban China: New Insights from Adult Literacy Measurement”, International Centre for the Study of East Asian Development, Kitakyushu, Working Paper Series 2003-21, August.

Giles, John, Albert Park and Juwei Zhang, 2005, “What is China’s True Unemployment Rate?”, China Economic Review, 16, pp. 149-170.

Godoy, Sergio and Joseph E. Stiglitz, 2006, “Growth, Initial Conditions, Law and Speed of Privatization in Transition Countries: 11 Years Later”, NBER Working Paper No. 11992, Cambridge, MA.

Goldstein, Morris and Nicholas Lardy, 2004, "What Kind of Landing for the Chinese Economy”, Policy Brief (Nov.), Washington DC: Institute for International Economics.

Guan, Xinping, 2000, “China’s Social Policy: Reform and Development in the Context of Marketisation and Globalisation”, Social Policy \& Administration, 34(1), pp. 115130.

Guo, Kai and Yang Yao, 2005, “Causes of Privatization in China. Testing Several Hypotheses”, Economics of Transition, 13(2), pp. 211-238.

Hannum, Emily, 1999, "Poverty and Basic-Level Schooling in China: Equity Issues in the 1990s”, Prospects: Quarterly Review of Comparative Education, 29(4), pp. 561577.

Harris, J. and Todaro, M., 1970, “Migration, Unemployment and Development: A TwoSector Analysis”, American Economic Review, 60, pp. 126-142.

Hart, Oliver, 1995, Firms, Contracts and Financial Structure, Oxford: Clarendon Press. Hayek, Friedrich von, 1945, “The Use of Knowledge in Society”, American Economic Review, 35(4), pp. 519-530.

Heckman, James J., 2005, “China’s Human Capital Investment”, China Economic Review, 16, pp. 50-70.

Hesketh, Therese and Wei Xing Zhu, 1997, "Health in China: The Healthcare Market, British Medical Journal, 314, p. 1616.

Heston, Alan, 2003, “Treatment of China in PWT 6”, mimeo, December. At http://pwt.econ.upenn.edu/Documantation/China.

Heytens, Paul and Harm Zebregs, 2003, “How Fast Can China Grow?”, in Wanda Tseng and Markus Rodlauer (eds.), China Competing in the World Economy, Washington DC: International Monetary Fund, pp. 8-29. 
Holz, Carsten A., 2005a “The Institutional Arrangements for the Production of Statistics”, OECD Statistics Working Paper, STD/DOC, 1, Paris: OECD. , 2005b,’China’s Economic Growth 1978-2025: What We Know Today about China’s Economic Growth Tomorrow”, mimeo, 2 November, Social Science Division Hong Kong University of Science \& Technology.

---------------, 2006, “Revisions to China’s GDP Data Following the 2004 Economic

Census: More Questions Than Answers?”, mimeo July, Social Science Division Hong Kong University of Science \& Technology.

Hsiung, Deh-I (2002), An Evaluation of China's Science and Technology System and its Impact on the Research Community, A Special Report for the Environment, Science and Technology Section, US Embassy, Beijing.

Hu, Albert G. Z., 2003, “R\&D and Technology Transfer: Firm-Level Evidence from

Chinese Industry”, Review of Economics and Statistics (forthcoming).

Hussain, Athar, 2000a, “The Social Role of the Chinese State Enterprise”, in Warner, Malcolm (ed.), Changing Workplace Relations in the Chinese Economy: Beyond the Iron Rice Bowl, New York: Palgrave Macmillan. , 2000b, "Social Welfare in China in the Context of Three Transitions",

Working Paper No. 66, Center for Research on Economic Development and Policy Reform, Stanford University. , 2003, Urban Poverty in China: Measurement. Patterns and Policies,

Geneva: International Labour Organization.

IFC, International Finance Corporation, 2000, China's Emerging Private Enterprises:

Prospects for the New Century, Washington DC: International Finance Corporation. IIE, 2006, China: The Balance Sheet, Washington DC: Institute for International

Economics and Center for Strategic and International Studies.

Iskander, Magdi, 1996, “Improving State-Owned Enterprise Performance: Recent International Experience”, in Broadman, Harry G. (ed), Policy Options for Reform of Chinese State-Owned Enterprises, Washington, DC: World Bank.

Islam, Rizwanul, 1990, "Rural Poverty, Growth and Macroeconomic Policies: The Asian Experience”, International Labour Review, 129(6), pp. 693-714.

Jalan, Jyotsna and Martin Ravallion, 1999, “Are the Poor Less Well Insured? Evidence on Vulnerability to Income Risk in Rural China”, Journal of Development Economics, 58, pp. 61-81. 
, 2002, “Geographic Poverty Traps? A Micro Model of Consumption

Growth in Rural China”, Global Development Network, Washington, DC.

Jefferson, Gary H. 2005, “R\&D and Innovation in China: Has China Begun Its S\&T

Takeoff?”, Harvard China Revie, 5(2), pp. 44-50.

Jefferson, Gary H., Bai Huamao, Guan Xiaojing, and Yu Xiaoyun, 2005, “R\&D

Performance in Chinese Industry”, Economics of Innovation and New Technology, 15(4/5), pp. 345-366.

Jefferson, Gary H., Jian Su, and Yuan Zhang (2004), "Privatization and Restructuring in

China: Evidence from Shareholding Ownership, 1995-2001”, manuscript, July 22.

Johnson, D. Gale, 1996, “China’s Rural and Agricultural Reforms: Successes and Failures”, Working Paper No. 96/12, Chinese Economics Research Centre, University of Adelaide.

, 1998, “China’s Rural and Agriculture Reforms in Perspective”, Paper

prepared for Land Tenure, Land Market, and Productivity in Rural China

Workshop, Beijing May 15-16.

Jones, Derek, Cheng Li and Ann Owen, 2003, “Growth and Regional Inequality in China during the Reform Era”, Working Paper No. 561, William Davidson Institute, Ann Arbor, MI.

Jourmard, Isabelle and Per Mathis Kongsrud, 2003, “Fiscal Relations across Government Levels”. Economics Department Working Papers No. 375, Paris: OECD.

Kanbur, Ravi and Ziaobo Zhang, 2005, "Fifty Years of Regional Inequality in China: A Journey Through Evolution, Reform and Openness”, Review of Development Economics, 91(1), pp. 87-106.

Khan, M. and A. Senhadji, 2000, "Financial Development and Economic Growth: An Overview”, IMF Working Paper No. 00/209, Washington, DC.

Kin, L.M., Y. Hui, Z. Tuohong, Z. Zijun, F. Wen and C. Yude, 2002, The Role and Scope of Private Medical Practice in China, mimeo, commissioned by UNDP, WHO, MOH China.

Knight, John and Linda Yueh, 2004, “Job Mobility of Residents and Migrants in Urban China”, Journal of Comparative Economics, 32, pp. 637-660.

Kuijs, Louis, 2005, “Investment and Saving in China”, World Bank Policy Research Working Paper Series No. 3633, Washington, DC. 
Kuijs, Louis, and Tao Wang, 2005, “China’s Pattern of Growth: Moving to Sustainability and Reducing Inequality”, World Bank Policy Research Working Paper Series No. 3767, Washington, DC.

Lange, Oskar, 1938, On the Economic Theory of Socialism, Minneapolis: University of Minnesota Press.

Lardy, Nicholas R., 2000, “When Will China’s Financial System Meet China’s Needs?”, mimeo, Center for Research on Economic Development and Policy Reform, Stanford University.

Lau, Lawrence J., Yingyi Qian and Gérard Roland, 1998, "Reform without Losers: An Interpretation of China’s Dual-track Approach to Transition”, CEPR Discussion Paper No. 1798.

Lerner, Abba, 1934, “Economic Theory and Socialist Economy”, Review of Economics and Statistics, II, pp. 51-61.

Levine, Ross, 1997, “Financial Development and Economic Growth: Views and Agenda”, Journal of Economic Literature, 35(2), pp. 688-726.

Lewis, Arthur, 1954, “Economic Development with Unlimited Supply of Labor”, Manchester School of Economics and Social Studies, 22, pp. 139-191.

Leydesdorff, Loet and Zhou Ping (2005), “Are the Contributions of China and Korea Upsetting the World System of Science”, Scientometrics, 63(3), pp. 617-630.

Li, David Daokui, Jiangyong Lu, and Zhigang Tao, 2006, Export and Productivity of China’s Indigenous Firms”, mimeo, Chinese Economists Society, Conference in Shanghai, July 1-2.

Li, Guo, Scott Rozelle and Jikun Huang, 2000, “Land Rights, Farmer Investment Incentives, and Agricultural Production in China”, Working Paper No. 00-024, Department of Agricultural and Resource Economics, University of California Davis.

Li, Hogbin, Pak Wai Liu, Ning Ma, and Junsen Zhang, 2005, “Does Education Pay in Urban China? Estimating Returns to Education Using Twins”, mimeo, Department of Economics of the Chinese University of Hong Kong.

Li, Mei, 2004, “Firm-based Training Programs and Workforce Developments in Mainland China”, Report to World Bank Institute, Washington, DC.

Lin, Songhua, 2003, “International Trade, Location and Wage Inequality in China”, Wider Discussion Paper No. 2003/61, Helsinki. 
Lindbeck, Assar, 1974, Swedish Economic Policy, Berkeley: California University Press, and London: Macmillan 1975.

, 1975, "Economic Systems and the Economics of the New Left", in Der

Streit um die Gesellschaftsordnung, Lectures at the University of Zurich, Zurich:

Schulthess Polygraphischer Verlag, pp. 91-112.

1995, “Hazardous Welfare-state Dynamics”, American Economic

Review, 85(2), pp. 9-15.

-, 2002,’The European Social Model: Lessons for Developing Countries”,

Asian Development Review, 19(1), pp. 1-13.

, 2005, “Ekonomiska Reformer och Social Utveckling i Kina” (Economic

Reforms and Social Development in China), Ekonomisk Debatt No 6, pp. 63-88.

-------------------, 2006, “Sustainable Social Spending”, International Tax and Public

Finance.

Lindbeck, Assar, Sten Nyberg and Jörgen W. Weibull, 1999, "Social Norms and Economic Incentives in the Welfare State”, Quarterly Journal of Economics, 114(1)

pp. 1-35.

Lindelöw, Magnus and Adam Wagstaff, 2005, “China Health Sector Issues Note”, mimeo,

Research Department, World Bank, Washington, DC.

Lipton, Michael and Martin Ravallion, 1995, "Poverty and Policy”, in Behrman, Jere, and

T.N. Srinivasan (eds.), Handbook of Development Economics, Volume III,

Amsterdam: Elsevier.

Liu, Lee, 2006, “Fertility Trends, Economic Growth, and Policy Reform in China”,

Congress of China Economists Society, Shanghai, July 2-4.

Liu, Zhiqiang, 2002, “Foreign Direct Investment and Technology Spillover: Evidence from

China”, Journal of Comparative Economics, 30(3), pp. 579-602.

Ljunggren, Börje, 2006, “China: Global Ascent and Domestic Dilemmas”, mimeo, Swedish Embassy, Beijing.

Luo Renfu, Linxiu Zhang, Jikun Huang and Scott Rozell, 2006, mimeo, paper presented at Chinese Economists Society, July 1-3.

Luo, Xubei, 2005, “Growth Spillover Effects and Regional Development Patterns: The

Case of Chinese Provinces”, World Bank Policy Research Working Paper No. 3652, Washington DC.

McKinsey Global Institute, 2006, Putting China's Capital to Work: The Value of Financial System Reform, San Francisco: McKinsey\&Company, 
Maddison, Angus, 1998, Chinese Economic Performance in the Long Run, Paris: OECD, and Maddison homepage, www.ggdc.net/maddison. , 2003, The World Economy; Historical Statistics, Paris: OECD.

Maurer-Fazio, Margaret and Ngan Dinh, 2002, “Differential Rewards to, and Contributions of, Education in Urban China’s Segmented Labor Markets”, mimeo, Bates College, Lewiston, ME.

Meng, Xin, 2005, “Symposium: Poverty and Labor Markets in China, Journal of Comparative Economics, 33(4), pp. 641-643.

Mi, Zhou and Xiaoming Wang, 2000, “Agency Costs and the Crisis of China’s SOE”, China Economic Review, 11(3), pp. 297-317.

Ministry of Education (MOE), 2004, "Survey of the Educational Reform and Development in China”, Beijing; China Education and Research Network.

Ministry of Labor and Social Security (MOLSS ), 1998, Questions and Answers on Unifying the Enterprise Basic Old-Age Insurance System, Beijing: China Labor Press.

, 2005, homepage, www.molss.gov.cn.

Ministry of Science and Technology (MOST), homepage, www.most.gov.cn.

Modigliani, Franco and Shi Larry Cao, 2004, “The Chinese Saving Puzzle and the LifeCycle Hypothesis”, Journal of Economic Literature, 42(1), pp. 145-170.

Nelson, Richard R. and Edmund S. Phelps, 1966, “Investment in Humans, Technological Diffusion and Economic Growth”, American Economic Review, 56, pp. 69-75. Nolan, Peter, 2004, China at the Crossroads, Cambridge: Cambridge Polity Press.

OECD, 2002, China in the World Economy, The Domestic Policy Challenges, Paris: OECD.

OECD, 2005a, Economic Surveys: China, Volume 2005/13, Paris: OECD.

OECD, 2005b, OECD Review of Agriculture Policies - China, Paris: OECD.

OECD, 2006, Challenges for China's Public Spending: Toward Greater Effectiveness and Equity, Paris: OECD.

Oi, Jean C. and Andrew G. Walder, 1999, Property Rights and Economic Reform in China, Stanford, CA: Stanford University Press.

Oxford Analytica, 2005, “China: Census Expands Size of Economy”, December 2005, http://www.oxan.com

Peerenboom, Randall, 2002, China’s Long March Toward Rule of Law, Cambridge: Cambridge University Press. 
, 2003, "Networks, Rule of Law and Economic Growth in China: The

Elusive Pursuit of the Right Combination of Public and Private Ordering”, Global Economic Review, 31(2).

People's Bank of China (2004), Survey of SME Financing Structure in China, Beijing. People Daily, 2005, “Top Statistician on China’s Economic Figures: Services Sector”,

December 22, http://english.peopledaily.com.cn

Pei, Minxin, 2006, China’s Trapped Transition: The Limits of Developmental Autocracy, Cambridge, MA: Harvard University Press.

Phelps, Edmund, 2005, Verbatim Transcript, Beijing Forum (memo).

Phillips. Kerk L. and Shen Kunrong, 2005, "What Effect Does the Size of the State-owned

Sector Have on Regional Growth in China?”, Journal of Asian Economics, 15(6), pp. 1079-1102.

Prasad, Eswar, Thomas Rumbaugh and Qing Wang, 2005, "Putting the Cart Before the Horse? Capital Account Liberalization and Exchange Rate Flexibility in China”, IMF Policy Discussion Paper, Washington, DC.

Ravallion, Martin and Shaohua Chen, 2003, “Measuring Pro-poor Growth”, Economics Letters, 78, pp. 93-99.

-------------------, 2006, “China’s (Uneven) Progress Against Poverty”, Journal of

Development Economics.

Renwei, Zhao, 2000, “”Increasing Income Inequality and Its Causes in China”, The Chinese Economy, July-August, pp. 8-27.

Rock, Michael T. and Heidi Bonnett, 2004, “The Comparative Politics of Corruption:

Accounting for the East Asian Paradox in Empirical studies of Corruption, Growth and Investment”, World Development, 32(6), pp. 999-1017.

Rozelle, Scott and Guo Li, 1998, “Village Leaders and Land-Rights Formation in China”, The American Economic Review, 88(2), pp. 433-438.

Schott, Peter K., 2005, “The Relative Sophistication of Chinese Exports”, memo ,Yale School of management, March.

Sleifer, Andrei and Vishny, Robert, 1993, “Corruption, Quarterly Journal of Economics, 108, pp. 599-617.

Schwaag Serger, Sylvia and Erik Widman, 2005, Konkurrensen från Kina (Competition from China), ITPS (Swedish Institute for Growth Policy Studies), Stockholm: Elanders. 
Sen, Amartya, 1985, Commodities and Capabilities, Amsterdam: North-Holland. -, 1995, “The Political Economy of Targeting”, in Dominique van de Walle and Kimberly Nead (ed.), Public Spending and the Poor, Washington, DC: World Bank

Siebert, Horst, 2006, “China - Understanding a New Global Economic Player”, Kiel Working Paper, No. 1278.

Social Insurance Research Team, 2003.

Social Policy Research Centre, 2002, “Reform of China’s Social Insurance System”, in Yang Tuan (ed.), Social Policy in China, Beijing: Chinese Academy of Social Sciences.

Song, Xiaowu, 2002, “China’s Social Security Systems and Old-Age Pension Funds”, State Council Office for Restructuring Economic Systems in the People’s Republic of China, paper presented at Asian Development Bank Annual Meeting, Shanghai, May.

Sun, Bingyao and Yang Tuan, 2003, "State, Society and Market: The Restructuring of China’s Social Welfare Service System - A Report on the Comparative Studies on Social Welfare of Shanghai and Hong Kong, in Tuan, Yang (ed.), op. cit. Svensson, Jacob, 2005, “Eight Questions about Corruption”, Journal of Economic Perspectives, 19, pp. 19-42.

Tang, Jun, 1999, “Poverty and Poverty Alleviation in China”, in Ru, Xin et al. (eds.), Analysis and Forecast of the Social Situation in China in 1999.

Tian, Xueyuan, 2004, “Getting Old Before Getting Rich”, People’s Daily, November 16. The Economist, Sept 11 and Oct, 2, 2004; March 25, 2006; Oct 21, 2006.

Transparency International Corruption Perceptions Index, 2005, http://www.transparency.org

Tsang, Mun C., 2002, "Intergovernmental Grants and the Financing of Compulsory Education in China”, memo, June, Teachers College, Columbia University. Tseng, Wanda and Harm Zebregs, 2002, “Foreign Direct Investment in China: Some Lessons for Other Countries”, IMF Policy Discussion Paper No. PDP/02/3, Washington, DC: IMF.

Tuan, Yang (ed.), 2003, Social Policy in China, Social Policy Research Centre, Institute of Sociology, Beijing: Chinese Academy of Social Sciences.

UN, 2003, World Population Prospects: The 2002 Revision, New York: UN Population Division. 
UNDP, 2000, 2005 China: Human Development Report, New York: Oxford University Press.

, 2004, World Population Prospects: The 2004 Revision Population Database, UN

Department of Economics and Social Affairs, Population Division, March 2006, http://esa.un.org/unpp.

UNICEF, 2005, The State of the World's Children. Also www.unicef.org/sowc03/

UNESCO, 2005, Global Education Digest, Paris. Also www.uis.unesco.org/

UNPD, 2004, World Population Prospects: The 2004 Revision Population Database, UN

Department of Economic and Social Affairs, Population Division.

http://esa.un.org/unpp.

Walder Andrew (ed.), 1996, China’s Transitional Economy, Oxford: Oxford University

Press.

Wan, Guang H. and Enjiang Cheng, 2001, "Effects of Land Fragmentation and Returns to Scale in the Chinese Farming Sector”, Applied Economics, 33, pp. 183-194.

Wang, Dewen, 2006, “China’s Urban and Rural Old Age Security System: Challenges and Options”, China World Economy, 14(1), pp. 102-116.

Wang, Hua, Jun Bi, David Wheeler, Jinnan Wang, Deng Cao, Genfu Lu and Yuang Wang, 2004, “Environmental Performance Rating and Disclosure: China’s Green Watch Program”, Journal of Environmental Management, 71, pp. 123-133.

Wank, David L., 1999, “Producing Property Rights: Strategies, Networks, and Efficiency in Urban China’s Nonstate Firms”, in Oi, Jean C. and Andrew G. Walder (eds.), op. cit.

Wedeman, Andrew, 2002, "Development and Corruption: the East Asian Paradox, in E. T. Gomez (ed.), Political Business in East Asia, pp. 34-61, London: Routledge.

Warner, Malcolm and Ying Zhu, 2000, “The Origins of Chinese ‘Industrial Relations”, in Warner, Malcolm (ed.), Changing Workplace Relations in the Chinese Economy: Beyond the Iron Rice Bowl, New York: Palgrave Publishers.

Wei, Shang-Jin, and Yi Wu, 2003, “Globalization and Inequality: Intra-.Chinese Evidence”, memo, IMF, June, Washington, DC.

Wei, Yingqi and Xiaming Liu, 2004, ”Convergence or Divergence? Debate on China’s Regional Development”, Department of Economics, Lancaster University Management School, UK.

Wen, Guanzhong James, 2006, “The Rural Land Tenure System and the Worsening Fulltime Farmers’ Income”, mimeo, Department of Economics, Trinity College. 
Wen, Mei and Xiao-guang Zhan, 2001, “Capital Allocation in China”, in Lloyd and Zhang, eds. op. cit., Chapt 7.

West, Laraine A., 2004, “Demographic and Socioeconomic Status of China’s Minority Ethnic Population: Any Closing of the Gap?”, Eurasia Branch, International Programs Center, Population Division, U.S. Census Bureau, Washington, DC. Whalley, John and Shunming Zhang, 2004, "Inequality Change in China and (hukou) Labour Mobility Restrictions, NBER Working Paper No. 10683, Cambridge, MA. Whalley John, and Xian Xin, 2006, “China’s FDI and Non-FDI Economies and the Sustainability of Future High Chinese Growth”, NBER Working Paper No, W12249.

Wong, Christine, 1985, “Material Allocation and Decentralization: Impact of the Local Sector in Industrial Reform”, The Political Economy of Reform in Post-Mao China”, Cambridge Mass.: Harvard University Press.

Wong, Linda, 1998, Marginalization and Social Welfare in China, London: Routledge. Woo, Wing Thye, 1998, “Chinese Economic Growth: Sources and Prospects”, in Fouquin, Michel and Françoise Lemoine (eds.), The Chinese Economy, Economica, London. World Bank, 1996, China - Reform of State-Owned Enterprises, Report No. 14924-DHA, Washington, DC.

-------------, 2001, China - Overcoming Rural Poverty, A World Bank Country Study.

Washington, DC. , 2002, China: National Development and Sub-National Finance: A

Review of Provincial Expenditures, Washington, DC. -, 2003a, China - Promoting Growth with Equity, Country Economic

Memorandum, Report No. 24169-CHA, Washington, DC.

---------------, 2003b, Country Economic Memorandum (China), Washington, DC.

-------------, 2004, Economic Report for 2006, World Bank, Washington, DC.

World Bank, 2005, Governance Matters: Governance Indicators, Washington DC: World Bank.

World Development Indicators, 2006, http://devdata.worldbank,org/ wdi2006/ contents/ Section2.htm

World Resources Institute, 2005, Tables, http://earthtrends.wri.org.

WTO, World Trade Organization, 2006, International Trade Statistics (www.wto.org). 
Wu, Yanrui, 2006, “Why Does the Dragon Fly while the Elephant Walks?”, mimeo, paper presented for conference on “Dragon and the Elephant: China and India’s Economic Reforms”, Shanghai, June 30-July 2, 2006.

Xiaoyi, Hu, 1996, “Reducing State-Owned Enterprises’ Social Burdens and Establishing a Social Insurance System”, in Broadman, Harry G. (ed.), Policy Options for Reform of Chinese State-Owned Enterprises, Washington, DC: World Bank.

Xu, Lixin Colin, Tian Zhu and Yl-Min Lin, 2005, "Politician Control, Agency Problems and Ownership. Reform: Evidence from China”, Economics of Transition, 13(1), pp. 1-24.

Young, Alvyn, 2003, “Gold into Base Metal: Productivity Growth in the People’s Republic of China during the Reform Period”, Journal of Political Economy, 3(6), pp. 122061.

Zhang, Junsen, Yaohui Zhao, Albert Park, and Xiaoqing Song, 2005, “Economic Returns to Schooling in Urban China, 1988 to 2001”, Journal of Comparative Economics, 33, pp. 730-752.

Zhang, Juwei, 2004, “China’s urban Labor Market. Major Trend Analysis”, Institute of Population and labor Economics, China Academy of Social Science.

Zhang, Xiaobo, 2006, “Asymmetric Property Rights in China’s Economic Growth”, Discussion Paper No. 28, International Food Policy Research Institute, Washington, DC.

Zhang, Xiaobo, and Ravi Kanbur, 2005, "Spatial Inequality in Education and Health Care in China”, China Economic Review, 16, pp. 189-204.

Zhang, Yin, and Wan, Guanhua 2005, "Why Do Poverty Rates Differ From Region to Region? The Case of Urban China”, Journal of the Asia Pacific Economy, 10(4), pp. 446-462.

Zhang, Ziao-Guang, 2001, "External Shocks and the Long-term Growth of the Chinese Economy”, in Lloyd, Peter and Xiao-Guang Zhang (eds.), Models of the Chinese Economy, Edward Elgar, Cheltenham, chap. 9.

Zhang, Zongyui, Aying Liu, and Shujie Yao, 2001, “Convergence of China’s Regional Incomes 1952-1997, China Economic Review, 12, pp. 243-258.

Zhao, Yaohui and Jianguo Xu, 2002, “China’s Urban Pension System: Reforms and Problems”, Cato Journal, 21, pp. 395-414.

Zhou, Kate Xiao, 1996, How the Farmers Changed China: Power of the People, Boulder, CO: Westview Press. 
Zhu, Ling, 2006, “Old Age Security: A Case from Rural Suzhou”, China \&World Economy, 14(1) , pp 67-78. 